\title{
Tort Law in California: At the Crossroads
}

\author{
Neil M. Levy† \& Edmund Ursin $\ddagger$
}

During the 1960's and 1970's, the California Supreme Court inaugurated a revolution in tort law by radically enhancing the ability of accident victims to obtain compensation. ${ }^{1}$ This revolution is most frequently associated with Chief Justice Traynor, ${ }^{2}$ who jomed the court in 1940 and served as Chief Justice from 1964 to 1970. But Justices Mosk, Peters, Sullivan, Tobriner, and Chief Justice Wright also were imstrumental in reshaping California tort law. Indeed, the California tort revolution was brought about through agreement by a sold majority of the court, even in precedent-shattering cases. ${ }^{3}$ The unabashed judicial creativity exhibited by the court in establishing new avenues of tort recovery led to its emergence as the most influential state supreme court in the field of tort law.

Recently, however, the court's direction has been far less obvious. Defendants have prevailed on a number of major issues. ${ }^{4}$ For example,

Copyright $\odot$ 1979, by Edmund Ursin \& Neil M. Levy. This Article benefited from an unpubhished paper by Susan Eydenberg Westlake, J.D. candidate, 1979, University of San Diego. Ms. Westlake's paper discussed the award of pain and suffering damages in light of recent California Supreme Court decisions such as Borer v. American Airlines, Inc., 19 Cal. 3d 441, 563 P.2d 858, 138 Cal. Rptr. 302 (1977).

$\dagger$ Professor of Law, Golden Gate University. A.B. 1963, Cornell University; J.D. 1966, University of Chicago.

¥ Professor of Law, University of San Diego. A.B. 1964, J.D. 1967, Stanford University.

1. This Article is limited to a discussion of torts which involve physical injury. Different pohicy considerations frequently are present when dealing with economic loss. See James, Limitations on Liability for Economic Loss Caused by Negligence: A Pragmatic Appraisal, 25 VAND. L. Rev. 43 (1972). The California Supreme Court recognized this distinction when it refused to apply strict tort liabihty theory to nonphysical hann caused by defective products. See Seely v. White Motor Co., 63 Cal. 2d 9, 403 P.2d 145, 45 Cal. Rptr. 17 (1965).

2. See, e.g., Kalven, The Quest for Appropriate Standards, 53 CALIF. L. Rev. 189 (1965). The editors for the Harvard Law Review have written that Chief Justice Traynor "inspired a dramatic renaissance of the common law." 83 HARv. L. REv. 1769 (1970).

3. Some of the inost notable decisions were by a unanimous court. See, e.g., Brown v. Merlo, 8 Cal. 3d 855, 506 P.2d 212, 106 Cal. Rptr. 388 (1973) (declaring automobile guest statute unconstitutional); Greenman v. Yuba Power Products, Inc., 59 Cal. 2d 57, 377 P.2d 897, 27 Cal. Rptr. 697 (1963) (establishing strict hability in tort for defective products). Only Justice McComb frequently opposed the movement during the 1960's and 1970's. With his appointuneut in 1973, Justice Clark also opposed the dommant thrust of the torts revolution.

4. An early analysis which noticed these developments was G. SCHwARTz, REPORT TO THE 
in the 1977 companion cases of Borer $v$. American Airlines, Inc. ${ }^{5}$ and Baxter v. Superior Court, ${ }^{6}$ the court refused to sanction causes of action for loss of parent-child consortium by either a child or a parent. One inonth later, in Justus $v$. Atchison, ${ }^{7}$ the court refused to follow the "weight of authority" as it denied a wrongful death cause of action for the death of a stillborn fetus. Fimally, im the 1978 case of Daly v. General Motors Corp. ${ }^{8}$ the court extended the defense of comparative fault to strict products liability. actions. In these recent cases the court has shown neither the self-assurance nor the unanimity of the past. Justices Tobriner and Mosk, consistent colleagues in the tort revolution, now often differ, and each has voted with the majority im favor of defendants over the other's dissent. ${ }^{9}$

In this Article we will attempt to reconcile the major recent California tort cases. Our thesis is that the court is contmuing to follow the trend estabhshed during the Traynor years of expanding the imcidence of tort liability. Recent cases in which defendants have prevailed should be viewed primarily as cases that limit damages rather than liability. ${ }^{10}$ We will first examine cases in which the court has expanded the incidence of hability by allowing plaintiffs to shift losses to defendants in situations where the defendants were previously exempt from tort liability. We will then focus on "damages cases"- that is, on cases in which the true issue is the an1ount of compensation, even though the case nuay formally deal with whether to permit a cause of action. Finally, we will analyze the new inood of the court concerning damages and explore sone of the dangers implicit in this new approach.

I

INCREASING THE INCIDENCE OF LIABILITY

\section{A. The Intellectual Framework of the Traynor Era}

During the 1960's, the Califorma Suprene Court characterized

JoINT COMMITteE ON TORT LIABILITY 14-19 (1978) (unpublished report on file with the California Legislature Joint Committee on Tort Liability).

5. 19 Cal. 3d 441, 563 P.2d 858, 138 Cal. Rptr. 302 (1977).

6. 19 Cal. 3d 461, 563 P.2d 871, 138 Cal. Rptr. 315 (1977).

7. 19 Cal. 3d 564, 565 P.2d 122, 139 Cal. Rptr. 97 (1977).

8. 20 Cal. 3d 725, 575 P.2d 1162, 144 Cal. Rptr. 380 (1978).

9. Compare Daly v. General Motors Corp., 20 Cal. 3d 725, 757, 575 P.2d 1162, 1181, 144 Cal. Rptr. 380, 399 (1978) (Mosk, J., dissenting) with Walters v. Sloan, 20 Cal. 3d 199, 207, 571 P.2d 609, 614, 142 Cal. Rptr. 152, 157 (1977) (Tobriner, J., dissenting) (applying "fireman's rule" to deny recovery to policeman injured while making arrest at party given by defendant).

10. We recognize that individual cases presented in this Article frequently can be explained solely by analyzing the legal doctrines involved in those cases. This is, of course, a useful and frequently necessary task for scholars and attorneys. In this Article, however, we are primarily attempting to establish an historical framework that interrelates the major trends of the California Supreme Court during the past twenty years. 
traditional limitations on tort recovery as accommodations to the perceived needs of economic growth during the nineteenth century. The court rejected this policy of nurturing infant industry as being inappropriate to a inature industrialized society. ${ }^{11}$ Accordingly, the court repeatedly replaced traditional doctrine with reforms that were premised on goals of loss distribution, accident reduction, and elementary fairness. Of these goals, the court einphasized loss distribution and the consequent spreading of accident costs throughout society. It thus avoided the academic debate annong and between advocates of accident reduction and fairness. ${ }^{12}$ The court believed, however, that its loss distribution approach would also reduce accident costs and achieve socially just results, without offending concepts of individual fairness. ${ }^{13}$

11. For cases placing traditional common law rules in historical perspective, see Rowland $v$. Christian, 69 Cal. 2d 108, 443 P.2d 561, 70 Cal. Rptr. 97 (1968); Muskopf v. Corning Hosp. Dist., 55 Cal. 2d 211, 359 P.2d 457, 11 Cal. Rptr. 89 (1961). Cf. Green v. Superior Court, 10 Cal. 3d 616, 517 P.2d 1168, 111 Cal. Rptr. 704 (1974) (implied warranty of habitability).

Legal scholars are in accord with the court's historical perspective. See, e.g., L. Friedman, A History OF AMERICAN LAW 409-24 (1973); M. HoRWITZ, THE TRANSFORMATION OF AMERICAN LAW, 1780-1860 (1977); J.W. HuRst, LAW AND THE Conditions of FREEDOM IN THE NineTEenth-Century UnIted STATES (1956); Malone, The Formative Era of Contributory Negligence, 41 ILL. L. Rev. 151 (1946). Historians have einpliasized similar themes. See, e.g., D. Boorstin, The Americans: The National Experience 35-42 (1965); L. Levy, The Law of the Commonwealth and Chief Justice Shaw (1957).

12. See Calabresi \& Hirschoff, Toward a Test for Strict Liability in Torts, 81 YaLE L.J. 1055 (1972); Epstein, Defenses and Subsequent Pleas in a System of Strict Liability, 3 J. LEGAL STUDIES 165 (1974); Epstein, A Theory of Strict Liability, 2 J. LEGAL STUDIEs 151 (1973); Fletcher, Fairness and Utility in Tort Theory, 85 HARv. L. REv. 537 (1972); Posner, Strict Liability: A Comment, 2 J. LEgAL STUdies 205 (1973).

13. We recognize that many of the court's decisions can be variously explained on loss distribution, accident reduction, or fairness grounds. As the discussion in part I of this Article indicates, however, the court's primary emphasis has been on loss distribution. See Traynor, The Ways and Meanings of Defective Products and Strict Liability, 32 TENN. L. REv. 363, 366 (1965). This policy emphasizes the desirability of spreading the inevitable risks of loss so as to reduce the impact on the injured individual of the costs of medical care and loss of income. Misfortune to the individual and the inevitable burden on society can be lessened, it is argued, if such losses are imposed on defendants who can distribute these costs through insurance. See Escola v. Coca Cola Bottling Co., 24 Cal. 2d 453, 462,150 P.2d 436, 440 (1944) (Traynor, J., concurring).

The expanded incidence of hability called for by the loss distribution pohicy is also consistent with the theory of accident reduction associated with Professor Calabresi. For example, in product liability cases, the theory is that imposing strict liability-as opposed to neghigence liabihityon the inanufacturer of a product will create a financial incentive to reduce the level of accidents below that likely to exist under a negligence standard. See, e.g., Calabresi \& Hirschoff, supra note 12, at 1074-76. On the other hand, contemporary economic theory does not supply definitive answers regarding the implications of the accident reduction policy. Compare Posner, supra note 12, at 221 with Calabresi \& Hirschoff, supra note 12, at 1059. And soine have recently questioned the extent to which tort liability does, in practice, influence accident levels. See P. ATrYaH, Accidents Compensation and the LAw 547-57 (2d ed. 1975); $J$. O'Connell, Ending Insult to INJURY 142 (1975). Thus, our analysis emphasizes the loss distribution goal, recognizing-along with the California Supreme Court-that the expanded incidence of hability indicated by this goal is likely also to reduce accident costs. See Ursin, Strict Liability for Defective Business Premises-One Step Beyond Rowland and Greenman, 22 U.C.L.A. L. REv. 820, 829 (1975).

Finally, a fairness rationale, see generally Fletcher, supra note 12, is particularly appropriate 
Our analysis, like the court's, will einphasize the goal of spreading accident losses through insurance.

The prevalence of hability insurance was an express preinise of the court's expansion of tort reinedies. When Justice Traynor first advocated the doctrine of strict products liability in his classic 1944 concurrence in Escola v. Coca Cola Bottling Co,${ }^{14}$ insurance was central to his proposal. He wrote that the "cost of an injury and the loss of tine or health inay be an overwlielming misfortune to the person injured."15 But it is "a needless one, for the risk of injury can be insured by the inanufacturer and distributed among the public as a cost of doing business." 16 Similarly, the "prevalence and availability of insurance" was one factor considered by the court when it abolished the traditional landowner rules in Rowland v. Christian. ${ }^{17}$ California tort decisions repeatedly have emphasized the desirability of spreading accident losses over society through insurance. ${ }^{18}$ The consequence has been the California tort revolution.

We turu now to a nore detailed examination of this tort revolution. We will first examine holdings that radically changed rules of law in discrete substantive areas. Then we will examine some of the inore subtle, doctrinal decisions that laid the groundwork for continued developinent of hability on a case-by-case basis in lower courts.

in suits between uninsured individuals, or where a court abolishes an exemption from negligence liability. But where tort law deals with whether to impose liability on business enterprises or insured individuals, a shift in analysis is necessary. See generally 2 F. HARPER \& F. JAMEs, THE LAW OF TORTS 762-63 (1956) [hereinafter cited as HARPER \& JAMrs]. In this context, holdings based on loss distribution can be seen as achieving socially just results without offending concepts of individual fairness. For example, strict liability is imposed on a manufacturer because it (not le or she) can distribute the loss through insurance and the cost of products.

14. 24 Cal. 2d 453, 461, 150 P.2d 436, 440 (1944) (Traynor, J., concurring).

15. Id at $462,150 \mathrm{P} .2 \mathrm{~d}$ at 441 .

16. Id

17. 69 Cal. 2d 108, 117, 443 P.2d 561, 567, 70 Cal. Rptr. 97, 103 (1968). See text accompanying notes 60-63 infra.

18. When the United States Court of Appeals for the District of Columbia Circuit adopted the Rowland holding in 1972, Judge Bazelon, writing for the court, surveyed the realignment of values in tort law. He articulated views shared by the California Supreme Court when lee wrote that there is a "continual movement away from fault as the governing principle for allocation of losses, in favor of enterprise liability or the distribution of losses over a larger segment of society through insurance." Simth v. Arbaugh's Restaurant, Inc., 469 F.2d 97, 101 (1972) (Bazelon, C.J.) (emphasis in original). For a seminal discussion of this theme, see 2 HARPER \& JAMEs, supra note 13 , at $762-63$.

Gregory and Kalven have written that insurance only became a "respectable" topic in tort discussions in the late 1950's and early 1960's. C. Gregory \& H. KALven, CASEs and MaterIALS ON TORTS 694 (2d ed. 1969). For a discussion of the benefits of spreading losses through tort liability, including the concept of secondary losses, see G. CALABRESI, THE CosTS OF ACCIDENTS (1970). 


\section{B. Reform of Discrete Areas of Liability}

\section{Products Liability}

The court's substance and style can best be seen in the area of strict liability for injuries caused by defective products. It took Justice Traynor nineteen years, froin his concurrence in Escola until the 1963 case of Greenman v. Yuba Power Products, Inc. ${ }^{19}$ to persuade the court to accept his view that "[a] inanufacturer is strictly liable in tort when an article he places on the inarket, knowing that it is to be used without inspection for defects, proves to have a defect that causes injury to a human being."20 In Greenman, as well as in subsequent products liability cases, the court explicitly used loss distribution concepts, einphasizing that the purpose of strict products liability is "to insure that the costs of injuries resulting from defective products are borne by the inanufacturers that put such products on the market rather than by the injured persons who are powerless to protect themselves."21

Subsequent products liability developments have been significant, thougli obviously not of the magnitude of Greenman. The court expanded the classes of defendants who can be sued under a strict products liability theory, lolding that enterprises within the chain of marketing and distribution of products are appropriate defendants. ${ }^{22}$ For example, in Vandermark v. Ford Motor Co. ${ }^{23}$ the court extended strict hability to retailers and in Price v. Shell Oil Co., ${ }^{24}$ to commercial bailors and lessors of personal property. In Price the court reiterated that the paramount policy to be promoted by the strict products liability rule "is the protection of otlerwise defenseless victims of manufacturing defects and the spreading throughout society of the cost of

19. 59 Cal. 2d 57, 377 P.2d 897, 27 Cal. Rptr. 697 (1963).

20. Id. at 62,377 P.2d at $900,27 \mathrm{Cal}$. Rptr. at 700 .

21. Id. at $63,377 \mathrm{P} .2 \mathrm{~d}$ at $901,27 \mathrm{Cal}$. Rptr. at 701.

22. It should also be clear that the implications of the loss distribution policy point to new areas of strict liability beyond the chain of production and distribution of products. As Justice Traynor pointed out over a decade ago, the strict liability rule of the products cases points to "a wealth of analogy yet to be developed." Traynor, supra note 13, at 376. Indeed, Justice Tobriner has argued, in part on the basis of the loss distribution policy, that courts should create strict liabihity rules to govern particular types of medical accidents. See Clark v. Gibbons, 66 Cal. 2d 399, 419-20, 426 P.2d 525, 540, 58 Cal. Rptr. 125, 140 (1967) (Tobriner, J., concurring). See also Note, Comparative Approaches to Liability for Medical Maloccurrences, 84 YALE L.J. 1141 (1975). Others have proposed that strict liability be imposed in cases of injuries caused by defective business premises, Ursin, supra note 13, or in cases of personal injury caused by defects in leased real property where the landlord is in the business of leasing, Love, Landlord's Liability for Defective Premises: Caveat Lessee, Negligence, or Strict Liability?, 1975 W1SC. L. Rev. 19. See also C. Gregory, H. Kalven \& R. Epstein, Cases and Materials on Torts 76 (3d ed. 1977); J. O'Connell \& R. Henderson, Tort Law, No-Fault and Beyond (1975).

23. 61 Cal. 2d 256, 391 P.2d 168, 37 Cal. Rptr. 896 (1964).

24. 2 Cal. 3d 245, 466 P.2d 722, 85 Cal. Rptr. 178 (1970). 
compensating them."25 The court also broadened the class of plaintiffs who can use the doctrine. Thus, in Elmore v. American Motors Corp. ${ }^{26}$ the court extended the benefits of the strict liability rule beyond users and purchasers to bystanders.

During the 1970's, the court, in several products cases, refused to allow traditional neghigence doctrines and defenses to thwart the loss distribution goal. For example, in 1972 the court, in Luque v. McLean, ${ }^{27}$ disallowed the defense of contributory negligence in strict products hability actions. Having thus forced defendants to concentrate on the assumption of risk defense, the court, in Horn v. General Motors Corp. ${ }^{28}$ narrowed that defense by refusing to allow an auto manufacturer to assert it against a driver who had failed to wear a seatbelt. The court held that for the defense to prevail against a strict hability theory, the defendant must prove an awareness by plaintiff of the specific danger and particular harm that might result. Since the plaintiff in.Horn was unaware of the particular defect in the steerimg mechanism, evidence of her failure to wear a seatbelt did not establish the defense of assumption of risk. Thus, between Luque and Horn, the court reduced the ability of manufacturers of defective products to avoid liability because of plaintiff' misconduct.

In Cronin v. J.B.E. Olson Corp. ${ }^{29}$ and Barker v. Lull Engineering Co. ${ }^{30}$ the court dealt with one of the crucial issues of strict products liability, the defect requirement. Section $402 \mathrm{~A}$ of the Restatement (Second) of Torts requires that a plaimtiff prove that the defective product is "unreasonably dangerous." 31 In Cronin, the court rejected the

25. Id. at 251, 466 P.2d at 726, 85 Cal. Rptr. at 182.

26. 70 Cal. 2d 578, 451 P.2d 84, 75 Cal. Rptr. 652 (1969).

27. 8 Cal. 3d 136, 501 P.2d 1163, 104 Cal. Rptr. 443 (1972). The court stated: "Ordinary contributory negligence does not bar recovery in a strict liability action. "The only form of plaintiff's negligence that is a defense to strict liability is that which consists in voluntarily and unreasonably proceeding to encounter a known danger, more commonly referred to as assumption of risk.'" Id at 145, 501 P.2d at 1169-70, 104 Cal. Rptr. at $449-50$ (emphasis in original) (quoting Barth v. B.F. Goodrich Tire Co., 265 Cal. App. 2d 228, 243, 71 Cal. Rptr. 306, 314 (1st Dist. 1968). The court has recently lield, however, that principles of comparative fault apply to strict products hability actions. Daly v. General Motors Corp., 20 Cal. 3d 725, 575 P.2d 1162, 144 Cal. Rptr. 380 (1978).

28. 17 Cal. 3d 359, 551 P.2d 398, 131 Cal. Rptr. 78 (1976).

29. 8 Cal. 3d 121, 501 P.2d 1153, 104 Cal. Rptr. 433 (1972).

30. 20 Cal. 3d 413, 573 P.2d 443, 143 Cal. Rptr. 225 (1978).

31. RESTATEMENT (SECOND) OF TORTS \& 402A(1) (1965) provides in full:

One who sells any product in a defective condition unreasonably dangerous to the user or consumer or to his property is subject to hability for physical larin thereby caused to the ultimate user or consumer, or to his property, if

(a) the seller is engaged in the busmess of selling such a product, and

(b) it is expected to and does reach the user or consumer without substantial change

in the condition in which it is sold.

See generally Prosser, Strict Liability to the Consumer in Califormia, 18 Hastings L.J. 9 (1966); Wade, Strict Tort Liability of Manufacturers, 19 Sw. L.J. 5 (1965). 
Restatement position because "it . . . [burdens] . . . the injured plaintiff with proof of an element which rings of negligence,"32 and "in practice rarely leads to a different conclusion than would have been reached under laws of negligence." ${ }^{33}$ The court thought that this result would undermine the purpose of strict liability as expressed in Greenman. ${ }^{34}$ The court chose instead to require only that a plaintiff prove "that there was a defect in the inanufacture or design of the product and that such defect was a proximate cause of the injuries." 35 Although the terin "defect" was not clearly defined, the court's holding encompassed both manufacturing and design defects. ${ }^{36}$

In Barker, the court gave substance to the defect concept, while reaffirming its intention not to let negligence-like concepts thwart strict liability principles. Under Barker, a product may be found to be defective in design in two ways. First, the plaintiff may demonstrate "that the product failed to perform as safely as an ordinary consumer would expect when used in an intended or reasonably foreseeable manner." 37 Second, a product "may be found defective in design, even if it satisfies ordinary consumer expectations, if through hindsight the jury determines that the product's design embodies 'excessive preventable danger,' or, in other words, if the jury finds that the risk of danger inherent in the challenged design outweighs the benefits of such design." 38

Giving plaintiffs two alternative routes to establish that a product is defective imcreases the incidence of compensation in products cases, especially in contrast to that attainable under Restatement standards. Moreover, with regard to the second defect definition, Barker facilitates plaintiff recovery by shifting the burden of proof to the defendant. ${ }^{39}$ The court justified this shift in the burden of proof by noting that its decisions "have repeatedly emphasized that one of the principal purposes behind the strict product liability doctrine is to relieve an imjured plaintiff of many of the onerous evidentiary burdens inherent in a neg-

32. 8 Cal. 3d at 132, 501 P.2d at 1162, 104 Cal. Rptr. at 442.

33. Id. at 133, 501 P.2d at 1162, 104 Cal. Rptr. at 442 (citations omitted).

34. See text accompanying note 21 supra.

35. 8 Cal. 3d at 133, 501 P.2d at 1162, 104 Cal. Rptr. at 442.

36. Id. at 134, 501 P.2d at 1162, 104 Cal. Rptr. at 442. Defense counsel in Barker argued that Cronin's disapproval of the "unreasouably dangerous" standard should be limited to manufacturing defects, and hence the standard should still apply in cases of design defects. The Barker court rejected this argument: "Indeed, in Cronin itself we cxpressly stated that our holding applied to design defects . . . 20 Cal. 3d 413, 426, 573 P.2d 443, 451, 143 Cal. Rptr. 225, 233 (1978) (citation omitted).

37. 20 Cal. 3d at 426-27, 573 P.2d at 452, 143 Cal. Rptr. at 234 (emphasis in original).

38. Id. at 430,573 P.2d at 454, 143 Cal. Rptr. at 236 (citations omitted).

39. "Once the plaintiff makes a prima facie showing that the injury was proximately caused by the product's design, the burden sliould appropriately shift to the defendant to prove, in light of the relevant factors, that the product is not defective." Id. at 431,473 P.2d at 455,143 Cal. Rptr. at 237. 
ligence cause of action." 40 Since "most of the evidentiary matters whicl may be relevant . . . under the 'risk-benefit' standard . . . are similar to issues typically presented in a negligent design case and involve technical inatters peculiarly within the knowledge of the manufacturer," 41 the manufacturer should be required to carry the burden of proof. Finally, the Barker opinion suggests even further expansion of liability in products cases: the court expressly left open the possibility of manufacturer liability for products for which no safer design is feasible. ${ }^{42}$

\section{Abolishing Exemptions from Negligence Liability}

The clear articulation of the loss distribution premise found in the products liability cases provides a frainework for understanding the sweeping reforms im other substantive areas of tort law. In each of the areas to be discussed, traditional tort doctrines tended to exempt or immunize defendants, even negligent defendants, from liability. Since 1960 the Califorma Supreme Court has responded to the conflict be-

40. Id.

In an earlier case, Ault v. International Harvester Co., 13 Cal. 3d 113, 528 P.2d 1148, 117 Cal. Rptr. 812 (1974), the court also eased plaintiffs' evidentiary burdens in products cases by holding that a statute that makes evidence of subsequent corrective actions inadmissible in negligence cases is not applicable to a strict products liabihity action. What is interesting in relation to Barker is that the opinion did not rest merely on a narrow discussion of the statutory language, but also drew support from the clash between the policies underlying the evidentiary rule and the policies underlyimg strict products liability: "when the context is transformed from a typical negligence setting to the modern products liability field, . . . the 'public pohicy' assumptions justifying this evidentiary rule are no longer valid." Id. at 120, 528 P.2d at 1151-52, 117 Cal. Rptr. at 815-16.

41. $20 \mathrm{Cal} .3 \mathrm{~d}$ at $431,573 \mathrm{P} .2 \mathrm{~d}$ at $455,143 \mathrm{Cal}$. Rptr. at 237.

42. Id. at 430 n. 10,573 P.2d at 455 n.10, 143 Cal. Rptr. at 237 n.10. The court rcferred to these as products whose "norm is danger," an idea derived from a 1965 article by Justice Traynor. See Traynor, supra note 13 , at $367-71$.

Since the negligence standard calls for a balancing of risks and benefits, Conway v. O'Brien, 111 F.2d 611, 612 (2d Cir. 1940) (L. Hand, J.), rev'd on other grounds, 312 U.S. 492 (1941), and Barker acknowledges that risks and benefits are to be weiglied in determining defectiveness, it could be argued that the negligence and strict liability issues are identical. See Scliwartz, Foreword: Understanding Products Liability, 67 CALIF. L. Rev. 435, 462-63 (1979). But this conclusion understates the court's often stated intention to expand the incidence of liability beyond negligence. The full array of holdings im Barker can be seen as the court's attempt to do precisely this, Thus, for example, the court created the consumer expectations test as an alternative route for plaintiff recovery to augment the risk-benefit test. In addition, the court shifted the burden of proof to defendants under the risk-benefit test. In practice, each of these rulings could markedly expand manufacturer liability. Also, the court indicated that juries are to weigh risks and benefits on the basis of hindsight, a holding that agam increases the incidence of hability beyond that established by negligence principles. Fimally, Barker not only leaves open, but dehiberately draws attention to the possibility of "nonn is danger" products hability. Thus, Barker not only expands the incidence of strict products liability but may itself be an intermediate step toward further expansion-imcluding strict liability for products that would not be considered defective in any ordinary sense. See Ursin, supra note 13, at 828 n.38. 
tween these barriers to recovery and the loss distribution premise by abohshing traditional rules.

For example, doctrines of imtrafamily immunity traditionally barred tort suits among various members of a family. ${ }^{43}$ During a ten year period beginning im 1962, the court abolished imterspousal immunity for both imtentional ${ }^{44}$ and neghigent torts ${ }^{45}$ and also abolished parental immunity for negligence liability. ${ }^{46}$ The court recognized that these doctrines had outlived any conceivable social purpose which they once might have served, and did not even feel it necessary to deal im any detail with a major rationale of the prior cases, that to allow such suits would discourage family harmony. ${ }^{47}$ Rather, the court focused on the reahistic recogmition that defendants im these suits, which often arise out of automobile accidents, will more than likely be insured. To mamtain intrafamily immunities would mean that losses would not be distributed through imsurance. The only substantial justification for this harsh result was the potential for collusion between plaimtiffs and named defendants (that is, family members). The court rejected this argument, emphasizing that the mere possibility of collusion should not be used to defeat the far more numerous legitimate claims. ${ }^{48}$ In abrogatimg the intrafamily immunities, the court imposed negligence liability in theory on family members and in reality on the companies insuring the family, ${ }^{49}$ thus furthering the loss distribution goal.

43. This immunity was adopted by the court in Peters v. Peters, 156 Cal. 32, 103 P. 219 (1909) (barring interspousal tort suits) and Trudell v. Leatherby, 212 Cal. 678, 300 P. 7 (1931) (barring unemancipated minors from suing parents for negligence). Plaintiffs sometimes attenupted to avoid these limitations by framing their complaints as if they were for settlement of property claims. See Spellens v. Spellens, 49 Cal. 2d 210, 239-42, 317 P.2d 613, 631-34 (1957) (Schauer, J., concurring and dissenting). For a thorough discussion of the topic, see McCurdy, Torts Between Persons in Domestic Relation, 43 HARv. L. Rev. 1030 (1930). See also Note, Interspousal Immunity from Tort: The Intentional-Negligent Distinction, 58 Nw. U. L. REv. 701 (1963).

44. Self v. Self, 58 Cal. 2d 683, 376 P.2d 65, 26 Cal. Rptr. 97 (1962).

45. Klein v. Klein, 58 Cal. 2d 692, 376 P.2d 70, 26 Cal. Rptr. 102 (1962).

46. Gibson v. Gibson, 3 Cal. 3d 914, 479 P.2d 648, 92 Cal. Rptr. 288 (1971). The court had previously abolished the parental immunity for "willful or unalicious" torts. Emery v. Emery, 45 Cal. 2d 421, 289 P.2d 218 (1955).

47. 3 Cal. 3d at 919, 479 P.2d at 651,92 Cal. Rptr. at 291 (1971). The court's lack of conceru over disrupted family harmony is indicated by the fact that even those opposed to abolition of the immunities focused on other issues. See Klein v. Klem, 58 Cal. 2d 692, 696, 376 P.2d 70, 73, 26 Cal. Rptr. 102, 105 (Schauer, J., dissenting).

48. See, e.g., Gibson v. Gibson, 3 Cal. 3d 914, 919-20, 479 P.2d 648, 651-52, 92 Cal. Rptr. 288, 291-92 (1971).

49. The insurance industry, however, has attenupted to reestablish these immunities by including family exclusion clauses in liability insurance policies. Sucl clauses exclude fron coverage neinbers of the insured's family, and liave the practical effect of reviving through contract the tort immunities abrogated by the court. See, e.g., California State Auto. Ass'n v. Warwick, 17 Cal. 3d 190, 550 P.2d 1056, 130 Cal. Rptr. 520 (1976) (imterpreting one such clause without ruling directly on the constitutionality of the statutes allowing such clauses). 
In 1961, Muskopf v. Corning Hospital District ${ }^{50}$ abolished the traditional doctrine of governmental immunity, ${ }^{51}$ thus allowing compensation for certain government-caused injuries that had previously been nonconipensable. Justice Traynor, writing for the court, critically examined early precedents and concluded that governmental immunity did not have the longstanding history and stature that some of its supporters claimed. More importantly, he focused on public policy considerations and particularly on the clear conflict between the old immunity rule and the policy of loss distribution: "If the reasons for ... the rule . . . ever had any substance they have none today. Public convenience does not outweigh individual conpensation, and a suit against a ... lospital district is against an entity legally and financially capable of satisfying a judgment.",52

After Muskopf, the California Legislature enacted the California Tort Claims Act. ${ }^{53}$ In subsequent decisions interpreting this Act, the court consistently denionstrated its desire to prevent the remnants of traditional sovereign immunity from unduly impeding the loss distribution goal. For example, in Johnson v. State ${ }^{54}$ the court held that Government Code section $820.2,55$ which provides immunity to the state when the public eniployee's injury-causing act or omission is the result of an "exercise of discretion," did not preclude liability where the allegation was that the state Youth Authority negligently failed to warn foster parents in whose hoine a sixteen-year old with homicidal tendencies was placed. The court rejected what it characterized as a purely semantic approach to the question of what is an "exercise of discretion," since such an approach would unduly restrict government liability. Instead, the court held that immunity should exist only in areas where "the responsibility for basic policy decisions has been committed to coordinate branches of government.".56 This new standard plays down the importance of whether "clioices" have been made. It appears to be based on a separation of powers concept designed to msulate the

50. 55 Cal. 2d 211, 359 P.2d 457, 11 Cal. Rptr. 89 (1961).

51. The court was clear, however, that the "[a]brogation of governmental immunity does not nean that the state is liable for all harms that result from its activities." Id. at 219-20, 359 P.2d at 462, 11 Cal. Rptr. at 94.

52. Id. at 216,359 P.2d at 459,11 Cal. Rptr. at 91.

53. CAL. Gov'T CODE $\$ \S 810-996.6$ (West 1966). The Legislature first adopted a two year moratorium on suits against governmental units. Moratorium Act (Public Liability), ch. 1404, 1961 Cal. Stats. 3209-10 (1961) (expired Sept. 20, 1963). In Corning Hosp. Dist. v. Superior Court, 57 Cal. $2 d 488,370$ P.2d 325, 20 Cal. Rptr. 621 (1962), the court approved the constitutionality of the Moratorium Act because it afforded public entities "time to prepare for bearing the burdens of defending actions and to provide for the satisfaction of possible judgments." Id. at 495,370 P.2d at 329, 20 Cal. Rptr. at 625.

54. 69 Cal. 2d 782, 447 P.2d 352, 73 Cal. Rptr. 240 (1968).

55. CAL. Gov't CoDE $\$ 820.2$ (West 1966).

56. $69 \mathrm{Cal} .2 \mathrm{~d}$ at $793,447 \mathrm{P} .2 \mathrm{~d}$ at $360,73 \mathrm{Cal}$. Rptr. at 248 (emphasis in original). 
government only from liability for basic policymaking. The court then furtler limited even this immunity. It wrote that the "dispositive virtue" of its approach is that it "requires us to find and isolate tliose areas of quasi-legislative policy-making which are sufficiently sensitive to justify [immunity]." 57 The court also relied on a familiar policy justification for limitmg immunity: "Since the entire population of California benefits from the activity of the Youth Authority, it should also share equally the burden of injuries negligently inflicted on individual citizens; suits against the state provide a fair and efficient means to distribute these losses." 58 The Johnson approach imdicates that many areas that observers in the past liave assunied to be immune may no longer be so. ${ }^{59}$

Immunity from liability for negligence also characterized traditional rules governing the tort liability of owners and occupiers of land. Plaintiffs were classified as trespassers, licensees, or invitees with special rules regarding recovery applied to each. ${ }^{60}$ As might be expected, these rules were complex and often liarsh. ${ }^{61}$ In 1968, the court, in the landmark case of Rowland $v$. Christion, ${ }^{62}$ recognized that the traditional classifications were historical anomalies which reflected views contrary to modern conceptions of social policy. The court discarded these classifications and concluded that the proper test for imposing liability on the land occupier for mjuries incurred on his premises is a negligence test: did the land occupier act reasonably in the management of the property? In support of its lolding, the court explicitly noted "the prevalence and availability of insurance" as being annong the major factors which should determine "whether immunity should be conferred upon the possessor of land."63 Rowland again shows traditional rules immunizing a class of defendants from negligence lia-

57. Id. at 794, 447 P.2d at 360-61, 73 Cal. Rptr. at 249-50 (emphasis added).

58. Id. at 797-98, 447 P.2d at 363,73 Cal. Rptr. at 251.

59. See K. Davis, Administrative LAw TeXt 477-79, 480-83 (3d ed. 1972). Davis calls Johnson "the outstanding opinion on the subject," id. at 477, and suggests that it "could be an especially helpful guide for the federal courts" in interpreting the "discretionary function" exception of the Federal Tort Claims Act. Id. at 483.

60. Under the traditional scheme, a land occupier owed a full duty to exercise reasonable care only to invitees. See, e.g., Oettinger v. Stewart, 24 Cal. 2d 133, 148 P.2d 19 (1944). Trespassers and licensees liad lesser chances for recovery. See generally 2 HARPER \& JAMES, supra note 13, at 1429-1505; W. PROSSER, HANDBOOK OF THE LAW OF TORTS 351-99 (4th ed. 1971) (heremafter cited as Prosser); Restatement (SeCOND) OF ToRTs \$\$ 328E-44 (1965).

61. Compare King v. Lennen, 53 Cal. 2d 340, 348 P.2d 98, 1 Cal. Rptr. 665 (1959) (overruling a long line of cases to allow liability to certain trespassing children) with O'Keefe v. South End Rowing Club, $64 \mathrm{Cal}$. 2d 729, 414 P.2d 830, 51 Cal. Rptr. 534 (1966) (denying liability to trespassing minor).

62. 69 Cal. 2d 108, 443 P.2d 561, 70 Cal. Rptr. 97 (1968).

63. Id. at 117,443 P.2d at 567, 70 Cal. Rptr. at 103 . 
bility giving way under critical scrutiny of a court committed to spreading accident costs through hability insurance.

In jurisprudential terms, Brown v. Merlo, ${ }^{64}$ decided in 1973, went even further than the previously discussed cases to assure that neghigent acts lead to liability. The immunity in Brown was created by a statute, ${ }^{65}$ not a common law rule. Brown involved the application of an autoinobile guest statute to negate neghigence hability in a suit by an automobile passenger against the driver lost. The court declared that portion of the statute to be in violation of equal protection primciples and lence unconstitutional. The court rejected the assertion that the justifications for the legislative classification-that the statute encouraged hospitality and protected against collusive lawsuits-provided a rational basis for the differential treatınent accorded by the statute's classification schenie. Much of the court's reasoning drew upon the intrafamily immunity cases. For example, the court conceded that the statute may prevent some collusive suits. But the statutory classification scheme was "far too gross and overimclusive to be justified by this end since the statute bars the great majority of valid suits along with fraudulent claims." 66 Also, the protection of liospitality rationale failed "to explain why the statute accords differential treatment to automobile guests as distinguished from all other guests." 67 The court focused on insurance and the desirability of spreading losses. It wrote that the guest statute "completely iguores the prevalence of liability insurance coverage today, a factual developinent which largely undermines any rational comection between the prevention of suits and the protection of hospitality." 68

Curiously, in 1976 in Schwalbe v. Jones, ${ }^{69}$ over the dissents of Justices Tobriner and Mosk, the court salvaged part of the automobile guest statute ${ }^{70}$ by upholding its application to a guest who happened

64. 8 Cal. 3d 855, 506 P.2d 212, 106 Cal. Rptr 388 (1973). read:

65. CAL. VEH. CODE $\$ 17158$ (West 1971) (amended 1973) (automobile guest statute) which

No person riding in or occupying a vehicle owned by him and driven by another person with his permission and no person who as a guest accepts a ride in any vehicle upon a highway without giving coinpensation for such ride, nor any other person, has any right of action for civil damages against the driver of the vehicle or against any other person legally liable for the conduct of the driver on account of personal injury to or the death of the owner or guest during the ride, unless the plaintiff in any such action establislies that the injury or death proximately resulted from the intoxication or willful misconduct of the driver.

66. $8 \mathrm{Cal} .3 \mathrm{~d}$ at 859,506 P.2d at 215, $106 \mathrm{Cal}$. Rptr. at 391 .

67. Id at 859,506 P.2d at 215, 106 Cal. Rptr. at 391 (emphasis in original).

68. Id.

69. 16 Cal. 3d 514, 546 P.2d 1033, 128 Cal. Rptr. 321 (1976), vacating 534 P.2d 73, 120 Cal. Rptr. 585 (1975).

70. After Brown, the Legislature amended the statute to apply only to owner occupants. See Automobile Guest Statute, 1973 Cal. Stats. 1426. 
also to be the owner of the automobile. Two years later, however, in Cooper v. Bray, ${ }^{71}$ a majority of the court adopted Justice Tobriner's and Justice Mosk's position. In Cooper the court declared that it is a violation of equal protection to deny compensation to this small class of automobile guest victims. Cooper thus indicates that the court today nay continue to include equal protection doctrine in its arsenal of tools to erase statutory limitations on hability for negligence.

Although it is not generally thought of as an immunity doctrine, the contributory neghigence rule can be so analyzed. During the nineteenth century the doctrine could fairly have been called the rule of railroad and industrial immunity. The all or nothing aspect of the rule, coupled with the treatinent of the issue as one of law rather than fact, ${ }^{72}$ gave courts the power to keep the hability issue from juries (which were noted for deeiding in favor of injured plaintiffs). Professor Malone has called the contributory neghigence rule an "ingenious device which gave the court almost complete freedom to accept or reject jury participation at its pleasure." 73 The rule was an integral component of a tort law system designed to minimize railroad and other industrial liability. In nore recent years, the doctrine served to immunize neghigent autonuobile drivers (and their insurance companies) from liability if the injured plaintiff had been negligent in even the shightest degree.

In 1975, the court, in Li v. Yellow Cab Co. ${ }^{74}$ abolished the doctrine of contributory negligence and adopted a systein of pure comparative negligence. The court thereby greatly increased the incidence of defendant liability. After $L i$, plaintiff negligence no longer completely bars recovery in negligence suits; rather, damages are only "diminished in proportion to the amount of negligence attributable to the person recovering."75 The court rejected inodified coniparative negligence (a systen in which plaimtiff fault, if great enough, totally bars recovery) in order to avoid merely shifting "the lottery aspect of the contributory negligence rule to a different ground."76 $L i$ recognizes that fault determinations should not completely frustrate the policy of loss distribution. ${ }^{77}$

The court's express disapproval in $L i$ of doctrines that totally bar recovery due to plaintiff's conduct led to a secondary holding dealing

71. 21 Cal. 3d 841, 582 P.2d 604, 148 Cal. Rptr. 148 (1978).

72. See, e.g., Baltimore \& Ohio R.R. v. Goodman, 275 U.S. 66 (1927).

73. Malone, The Formative Era of Contributory Negligence, 41 ILI. L. Rev. 151, 169 (1946).

74. 13 Cal. 3d 804, 532 P.2d 1226, 119 Cal. Rptr. 858 (1975).

75. Id. at 829,532 P.2d at 1243,119 Cal. Rptr. at 875 .

76. Id. at 827,532 P.2d at 1242,119 Cal. Rptr. at 874 .

77. For further discussions of $L i$, see text accompanying notes 190-91 infra. See also Levy, Pure Comparative Negligence: Set-offs, Multiple Defendants and Loss Distribution, 11 U.S.F. L. REv. 405, 408-12 (1977). 
with assumption of the risk. The court had previously exhibited its antagonism toward this defense ${ }^{78}$ which, like contributory neghigence, reflects the harshness of nineteenth century tort policy. $L i$ held that "the defense of assumption of risk [is merged] into the general scheme of assessment of liability in proportion to fault in those particular cases im which the form of assumption of the risk involved is no nore than a variant of contributory negligence." tiff unreasonably undertakes to encounter a specific known risk imposed by a defendant's neghigence." ${ }^{.80} L i$ has, therefore, been interpreted by many as abohishing the traditional defense of assumption of risk. ${ }^{81}$ The defense may now apply only "where plaintiff is held to agree to relieve defendant of an obligation of reasonable conduct toward him." 82

In Coulter v. Superior Court, ${ }^{83}$ decided in 1978, the court apphed negligence primciples to yet another previously untouched area by extending the primciple of drain shop liability to social hosts. ${ }^{84}$ The court held, both on the basis of the dram shop statute ${ }^{85}$ and on general negli-

78. See Grey v. Fibreboard, 65 Cal. 2d 240, 481 P.2d 153, 53 Cal. Rptr. 545 (1966) (failure to give instruction on assumption of risk not prejudicial error because the jury's implied verdict for the plaintiff on the contributory negligence issue guaranteed he did not unreasonably undertake a specific, known risk); Vierra v. Fifth Ave. Rental Serv., 60 Cal. 2d 266, 383 P.2d 777, 32 Cal. Rptr. 193 (1963) (no assumption of risk unless plaintiff had actual knowledge of the specific risk involved).

79. $13 \mathrm{Cal} .3 \mathrm{~d}$ at 825,532 P.2d at 1241,119 Cal. Rptr. at 873.

80. Id. at 824,532 P.2d at 1240,119 Cal. Rptr. at 872 (emphasis im original).

81. See G. Schwartz, Report to the State Legislature's Joint Committee on Tort LIABILITY: AsSUMPTION OF THE RISK 12-13, 17 (1978), reprinted in SERIES 1978 STAFF REPORT OF THE JONNT COMMITTEe ON TORT LIABILITY TO THE GOVERNOR AND LEgisLATURE 450, 465-66, 470 (1979). Schwartz argues that the doctrine of assumption of the risk should be retained, but shonld be "narrowly and rigorously defined." Id. at 20, 1978 STAFF REPORT at 473. Schwartz suggests that Walters v. Sloan, 20 Cal. 3d 199, 571 P.2d 609, 142 Cal. Rptr. 152 (1977) (retaining and extending the "fireman's rule"), is an assumption of the risk case, while conceding that the defense under the $L i$ and Daly combination "would appear to be in clcar retreat im California law." Id. at 17, 1978 STAFF REPORT at 470-71. For a contrary interpretation of Walters, see notes 181-86 and accompanying text infra. Recent cases that discuss assunption of risk show a sharp disfavor for the defense. See text accompanying note 78 supra. The Cahifornia Supreme Court has not expressly denied liability on an assumption of risk rationale since 1935. See Quimn v. Recreation Park Ass'n, 3 Cal. 2d 725, 46 P.2d 144 (1935) (bascball spectator struck by a batted ball).

82. 13 Cal. 3d at 824, 532 P.2d at 1240, 119 Cal. Rptr. at 879. See generally Flcming, Foreword: Comparative Negligence at Last-By Judicial Choice, 64 CALIF. L. Rev. 239, 260-67 (1976).

83. 21 Cal. 3d 144, 577 P.2d 669, 145 Cal. Rptr. 534 (1978).

84. In Coulter, the court built on earlier cases that established hability for damages resulting from furnishing alcoholic beverages to an intoxicated person. In 1971, the court had held that in appropriate cases hiability could be imposed on commercial vendors. Vesely v. Sager, 5 Cal. 3d 153, 486 P.2d 151, 95 Cal. Rptr. 623 (1971). See also Ewing v. Cloverleaf Bowl, 20 Cal. 3d 389, 572 P.2d 1155, 143 Cal. Rptr. 13 (1978); Bernhard v. Harrah's Club, 16 Cal. 3d 313, 546 P.2d 719, 128 Cal. Rptr. 215 (1976).

85. See Alcoholic Beverage Control Act, ch. $758 \S 94,1937$ Cal. Stats. (current version at 1978 Cal. Stats. clr. 929). At the time of the Coulter decision, the statute provided as follows: 
gence principles, "that a social host who furnishes alcoholic beverages to an obviously intoxicated person, under circumstances which create a reasonably foreseeable risk of harm to others, may be held legally accountable to those third persons who are injured when that harm occurs." ${ }^{\text {86 }}$ Coulter resembles cases previously discussed in this section. First, it imposed liability where immunity from hability had been the rule. Second, the availability of insurance was again relied on: "we may assume that insurance coverage (doubtless increasingly costly) will be made available to protect the social host from civil liability in this situation." $" 87$

Despite these similarities, important differences exist between Coulter and inany of the cases previously discussed. First, many social hosts, especially those in lower income levels, will not be insured. Perhaps because of this, the court in part justified its decision upon the moral blame ascribed to "anyone who mcreases the obvious intoxication of a guest under conditions involving a reasonably foreseeable risk of harin to otliers." 88 The prompt adverse legislative response to the Coulter decision ${ }^{89}$ suggests that the court's sense of morality conflicted with the realities of legislative politics and, perhaps, public attitudes. In any event, Coulter, like the other 1978 decisions in Barker and Cooper, confirms the court's commitment to promoting the compensation of accident victims.

\section{The Doctrinal Cases}

During the 1960's and 1970's, the California Supreme Court decided important cases which, because they involved more subtle doctrinal issues, did not attract as inuch attention as the decisions discussed above. Unusual fact patterns may also have obscured the broader implications of these cases. Nevertheless, these "doctrinal decisions" laid the groundwork for continued expansion of the incidence of tort liability.

\section{Res Ipsa Loquitur}

Prior to the explicit reforms of the 1960's and 1970's, the court, in a variety of contexts, held that a jury can appropriately base a verdict for the plaintiff on slight evidence of negligence and despite strong coun-

"Every person who sells, furnishes, gives, or causes to be sold, furnished, or given away, any alcoholic beverage to any habitual or common drunkard or to any obviously intoxicated person is guilty of a misdemeanor." But see note 89 infra.

86. $21 \mathrm{Cal}$. 3d at 147,577 P.2d at $670,145 \mathrm{Cal}$. Rptr. at 535.

87. Id. at 153,577 P.2d at 674,145 Cal. Rptr. at 539.

88. Id.

89. 1978 Cal. Stats., ch. 929 . The legislature in this act overruled not only the result in Coulter, but also prior cases holding commercial vendors liable. See note 84 supra. 
tervailing evidence in favor of the defendant. In addition, it held that plaintiffs could avail themselves of the doctrine of res ipsa loquitur in such circuinstances. An illustrative case is Escola v. Coca Cola Bottling Co. ${ }^{90}$ Plaintiff, a waitress, was imjured when a soda bottle broke in her hand. On appeal from a judginent in her favor against the bottling company, the court held that the fact that the bottle exploded and the plaintiff's testimony that she carefully handled the bottle were sufficient to support the jury verdict, despite defendant's evidence tending to show that it had taken considerable precautions. In addition, the court approved the use of res ipsa loquitur in this situation. In his concurring opinion, Justice Traynor wrote that "[i]n leaving it to the jury to decide whether the inference [of negligence] has been dispelled, regardless of the evidence against it, the negligence rule approaches the rule of strict liability."91

Even though the court subsequently adopted a strict hability rule in products cases, it emphasized that the res ipsa precedents remained a useful alternative, especially in cases in which it is difficult for plaintiffs to prove that a particular defect exists im a product. Thus, in the 1971 case, Jiminez v. Sears, Roebuck \& Co., ${ }^{92}$ the court held that a plaintiff can plead strict liability, res ipsa loquitur, and negligence. Also, a plaintiff "should not be denied the inference of negligence inerely because he lias presented some evidence of a defect or of specific acts of negligence."93

The expansive use of res ipsa loquitur has also occurred in the area of medical malpractice. Since the expert testimony necessary to establish negligence was often unavailable due to the well-known "conspiracy of silence" ainong doctors, ${ }^{94}$ even plaintiffs who were negligently injured rarely could succeed im a malpractice suit during the first half of this century. ${ }^{95}$ Res ipsa loquitur came to be one device used to assist

90. 24 Cal. 2d 453, 150 P.2d 436 (1944). See discussion of Justice Traynor's concurring opinion in notes 14-16 and accompanying text supra.

91. 24 Cal. $2 \mathrm{~d}$ at 463,150 P.2d at 441 (Traynor, J., concurring).

92. 4 Cal. 3d 379, 482 P.2d 681, 93 Cal. Rptr. 769 (1971).

93. Id. at $385-86,482$ P.2d at 685,93 Cal. Rptr. at 773.

Expansive res ipsa decisions have not been confined to cases that today would fall within the doctrine of strict products liability. For example, in Rose v. Melody Lane of Wilshire, 39 Cal. 2d 481, 247 P.2d 335 (1952) (Traynor, J.), the plaintiff was imjured when a bar stool in the defendant's cocktail lounge collapsed. The court held that there was sufficient evidence to justify a verdict for the plaintiff and stated that a res ipsa loquitur instruction would also be appropriate on these facts. By allowing the jury to decide for the plaintiff in Rose on slight evidence and despite the fullest of explanations by the defendant, the court greatly increased the incidence of liability. For further implications of Rose, see Ursin, supra note 13.

94. Hoffman v. Lundquist, 37 Cal. 2d 465, 484, 234 P.2d 34, 46 (1951) (Carter, J., dissenting).

95. Keeton, Compensation for Medical Accidents, 121 U. PA. L. REv. 590, 592 (1973). See generally Ybarra v. Spangard, 25 Cal. 2d 486, 154 P.2d 687 (1944) (expanding use of res ipsa loquitur "to avoid gross injustice"). 
negligently injured patients to overcoine barriers of proof. Moreover, its use by courts and its application by juries have been influenced by the saine perceived desirability of the loss distribution goal which influenced courts and juries in products cases. ${ }^{96}$ For example, in Clark $v$. Gibbons $^{97}$ the preinature termination of anesthesia brought an operation to a halt, producing an arthritic condition in the plaintiff. A strict application of the doctrine of res ipsa would have required the plaintiff to present evidence that this kind of accident ordinarily does not occur in the absence of negligence. Such a requirement would have posed familiar problems. Expert medical testimony may have been unavailable to the injured plaintiff; and, even if such testimony were generally available, plaintiff would still have been unable to recover if his imjury were too rare or little understood to permit meaningful statistical analysis of its probable cause. The court's response in Clark was to liberalize the doctrine of res ipsa loquitur. The court wrote: "proof that when due care is exercised an injury rarely occurs, accompanied by other evidence indicating negligence, may be sufficient to warrant an instruction on conditional res ipsa loquitur."98 As Chief Justice Traynor and Justice Tobriner pointed out, the standard used by the majority represents a liberalization of the traditional res ipsa requirement that there be common knowledge or expert testimony that, when such an accident occurs, it is more probably than not the result of negligence. Under the court's formulation, res ipsa could be used even where the record contains no evidence indicating that, in those rare cases in which an anesthetic does terminate preniaturely, a negligent cause is more probable than a nounegligent one. ${ }^{99}$

\section{Burden of Proof-Cause in Fact}

In 1970, the court showed similar creativity when, in Haft v. Lone Palm Hotel, ${ }^{100}$ it opened the door for changing the burden of proof on the issue of cause im fact in certaim cases. In Haft, suit was brought against a motel on behalf of the estates of a man and his son who had drowned while swimming im the motel pool. The motel had violated a statute that required that "lifeguard service shall be provided or signs

96. See, e.g., Escola v. Coca Cola Bottling Co., 24 Cal. 2d 453, 462, 150 P.2d 436, 441 (1944) (Traynor, J., concurring).

97. 66 Cal. 2d 399, 426 P.2d 525, 58 Cal. Rptr. 125 (1967).

98. Id. at 412,426 P.2d at 534,58 Cal. Rptr. at 134.

99. Id. at 415 n.2, 426 P.2d at 536 n.2, 58 Cal. Rptr. at 136 n.2 (Tobriner, J., concurring). See also id. at 422, 426 P.2d at 54l, 58 Cal. Rptr. at 141 (Traynor, C.J., concurring and dissenting).

100. 3 Cal. 3d 756, 478 P.2d 465, 91 Cal. Rptr. 745 (1970). In Haft, the court relied on the previous California case of Summers v. Tice, 33 Cal. 2d 80, 199 P.2d l (1948). In Summers one of two negligent hunters had injured the plaintiff, but which one was not known. The court held that the burden of proof shifted to the defendants on the question of causation. 
shall be erected clearly indicating that such service is not provided." 101 The court first held that the motel's conduct should be measured by its omission to provide lifeguard services. In addition, the court held that the burden of proof on the causation issue shifted to the defendant to prove that the absence of lifeguard services was not causally related to the drownings. The court wrote that shifting the burden of proof is "consistent with the emerging tort policy of assigning liability to a party who is in the best position to distribute losses over a group which should reasonably bear them." 102 Although the opinion leaves unclear the precise circumstances in which the Haft doctrine is applicable, the court paved the way for future reversals of the burden of proof on the "but for" test of causation in other contexts. ${ }^{103}$

\section{Vicarious Liability}

Maloney v. Rath, ${ }^{104}$ decided in 1968 , is another case in which the court reformulated traditional negligence doctrine to facilitate plaimtiff recovery and loss distribution. In Maloney, plaintiff was injured when her autoinobile was struck from behind by defendant's car. Defendant apparently was not neghigent and proved that her brakes failed because of the negligence of her garage mechanic. The unsafe brakes constituted a violation of safety provisions of the Vehicle Code. ${ }^{105}$ Before Maloney, failure to comply with safety provisions of the Vehicle Code gave rise to a presumption of negligence that a defendant could rebut by proof of what might reasonably be expected of a person of ordinary prudence who desired to comply with the law. ${ }^{106}$ In Maloney, defendant offered sufficient evidence to rebut the presumption that she was negligent, and probably would have prevailed under received doctrine. The court did not, however, look favorably on the existing law's limits

101. 3 Cal. 3d at 775 n.20, 478 P.2d at 477 n.20, 91 Cal. Rptr. at 757 n.20.

102. Id.

103. In Sindell v. Abbott Labs., Inc., 85 Cal. App. 3d 1, 149 Cal. Rptr. 138 (2d Dist. 1978), hearing granted, No. 78-178 (Cal. Sup. Ct., Dec. 11, 1978), the court of appeal relied on Haft to shift the burden of proof on causation to manufacturers of a drug, diethylstilbestrol (DES), where plaintiff was unable to name the particular defendant whose product caused the injury. Because the appeal was docketed by the California Supreme Court, the court of appeal decision ceases to have precedential value. See Krouse v. Nimocks, 8 Cal. 2d 482, 66 P.2d 438 (1937).

104. 69 Cal. 2d 442, 445 P.2d 513, 71 Cal. Rptr. 897 (1968).

105. Cal. Veh. Code $\$ 26300,1959$ Cal. Stats. 1733 (repealed 1965); Cal. Veh. Code $\S 26453$ (West 1971). Section 26300, in effect at the time of the accident, read:

Every motor vehicle . . . slall be equipped with brakes adequate to control the movcment of the vehicle and to stop and hold the vehicle.

Section 26453 read:

All brakes and component parts thereof shall be maintained in good condition and in good working order. The brakes shall be so adjusted as to operate as equally as practicable with respect to the wheels on opposite sides of the vehicle.

106. Alarid v. Vanier, 50 Cal. 2d 617, 624, 327 P.2d 897, 900 (1958) (affirming decision that defendant rebutted presumption of negligence). 
on the incidence of hability and compensation. ${ }^{107}$ Justice Traynor, writing for the court, held that "the duty to exercise reasonable care to maintain brakes so that they comply with the provisions of the Vehicle Code can [not] be delegated." 108 The effect of the court's expanded doctrine of vicarious liability was to enlarge the avenues of plaintiff recovery and, as the court exphicitly recognized, further the loss distribution goal by allowing suits against nonneghigent, financially responsible defendants (assuming mechanic negligence). ${ }^{109}$ The existence of widespread automobile liability insurance made this a particularly attractive result. Justice Traynor wrote:

The responsibility for minimizing [the risk caused by improperly maintained motor vehicles] or compensating for the failure to do so properly rests with the person who owns and operates the vehicle. He is the party primarily to be benefited by its use; . . . the cost of his liability insurance that distributes the risk is properly attributable to his activities .... ${ }^{110}$

\section{Concepts of Duty}

The court in the 1970's altered traditional "duty" concepts that had often been einployed to negate negligence liability. Previously, courts in a variety of circumstances had ruled that a plaintiff stated no cause of action because the defendant owed no "duty" to plaintiff."11 Weirum v. RKO General, Inc. ${ }^{112}$ decided in 1975, has the potential for eliminating many of these special duty exceptions to negligence liability. In Weirum, a radio station with a large teenage audience offered prizes to the first person able to locate a disc jockey who was travelling in his auto to a number of Los Angeles locations. His whereabouts and destination were broadcast periodically to the station's listeners. During the contest a minor attempted to follow the disc jockey's automo-

107. In Maloney, the court declined to hold, however, that a violation of a safety provision of the Vehicle Code makes the violator strictly liable for damages caused by the violation. This holding was not an endorsement of the efficacy of negligence law in the automobile accident context. In fact, Justice Traynor wrote: "We are aware . . . of the growing dissatisfaction with the law of negligence as an effective and appropriate means for governing compensation for the increasingly serious harms caused by automobiles." $69 \mathrm{Cal}$. $2 \mathrm{~d}$ at 445,445 P.2d at 514, $71 \mathrm{Cal}$. Rptr. at 898. Nevertheless, the court thouglit that the problem of compensation for traffic accidents requires a comprehensive plan more suitable for legislative enactment than common law development. Id. at 446, 445 P.2d at 515, 71 Cal. Rptr. at 899.

108. Id. at 446,445 P.2d at 515,71 Cal. Rptr. at 899 .

109. Id.

110. Id. at 448, 445 P.2d at 516, 71 Cal. Rptr. at 900.

111. See, e.g., Richards v. Stanley, 43 Cal. 2d 60, 271 P.2d 23 (1954) (owner has no duty to prevent possible imjury to third persons caused by thief's negligent driving of automobile). See generally Adams v. Southern Pac. Transp. Co., 50 Cal. App. 3d 37, 123 Cal. Rptr. 216 (3d Dist. 1975).

112. 15 Cal. 3d 40, 539 P.2d 36, 123 Cal. Rptr. 468 (1975). In Weirum, the court in part built on such cases as Dillon v. Legg, 68 Cal. 2d 728, 441 P.2d 912, 69 Cal. Rptr. 72 (1968). 
bile and negligently forced a third car off the road, killing the occupant. The court affirmed a judgment in favor of the surviving wife and children in their suit against the radio station. The court held that it was immaterial that the decedent's death was caused by the negligent or reckless actions of a third party. According to the court, the "primary question . . . is whether defendant owed a duty to decedent . . .."113 Altliough duty was seen as a question of law, foreseeability of the risk was found by the court to be the primary consideration in establishing duty, ${ }^{114}$ and this, in turn, was seen as a question of fact for the jury. The record supported a finding of foreseeability, and so the court affirmed the verdict in favor of the plaimtiff.

Weirum signifies that the court inay increasingly einphasize foreseeability of harm to avoid "duty limitations" on negligence hability. Indeed, recent affirmative duty cases have taken a similar approach, emphasizing foreseeability to establish affirmative duties in situations in which no duty previously existed. For exainple, in the 1976 case of Landeros v. Flood, ${ }^{115}$ the court lield that a doctor had an affirmative duty to a child patient to diagnose properly and report a so-called battered child syndrome in order to protect the patient from foreseeable intentional harms that may be inflicted by the child's parents. The court decided the case not only on narrow statutory grounds, but also on common law primciples that, the court einphasized, would lead to the saine result. ${ }^{116}$ The same year, in Tarasoff $\nu$. Board of Regents, ${ }^{117}$ the court went even further, finding error im the sustaining of a demurrer in a case in which plaimtiff's daughter was killed by a patient of defendant psychotherapist. Plaintiff had alleged that the therapist knew, or sliould have known, of the inurderer's intent, yet failed to warn the deceased. The court held that under these circumstances psychiatrists have an affirmative duty to third parties for torts committed by their patients. ${ }^{118}$ Much of the opinion dealt with defining the limits of the doctor-patient privilege. From a torts viewpoint, however, Tarasoff indicates that a special relationship between two parties can lead to an affirmative duty owed by one of those parties to a third party who was injured through actions of the other. In the future, this general primciple inay be extended beyond psychiatrists to hold other de-

113. Id. at 45,539 P.2d at 39, 123 Cal. Rptr. at 471 .

114. Id. at 46,539 P.2d at 39, 123 Cal. Rptr. at 471 (citations omitted).

115. 17 Cal. 3d 399, 551 P.2d 389, 131 Cal. Rptr. 69 (1976).

116. Id. at 413,551 P.2d at 396,131 Cal. Rptr. at 76.

117. 17 Cal. 3d 425, 551 P.2d 334, 131 Cal. Rptr. 14 (1976).

118. Justice Mosk concurred and dissented in a separate opinion. In his view, liability could be predicated only on a finding of actual knowledge of the danger by the doctor. Id. at $451-52$, 551 P.2d at 353-54, 131 Cal. Rptr. at 33-34. 
fendants liable to third parties because of relationships with persons who actually cause injury.

Landeros and Tarasoff are significant beyond their technical holdings because they support the assertion that Weirum signals the court's increasing emphasis on foreseeability to avoid duty limitations on tort recovery. ${ }^{119}$ Weirum itself has further significant implications, however. In the past, courts often treated duty as a question to be determined by the court as a matter of law. Using this device, courts could rule in favor of defendants, thus precluding jury decision. After Weirum, lowever, foreseeability of the risk is not just "a consideration" but "a primary consideration" in determining duty. Moreover, foreseeability is a question of fact. At the trial court level, the court's discretion to rule for defendants under doctrines of duty seems to be undercut substantially by Weirum. Precisely because foreseeability is both a primary consideration in determining duty and a question of fact for jury determination, far more cases inust go to the jury after Weirum. Moreover, appellate courts are limited in reviewing jury determinations of foreseeability and, therefore, also duty. For example, in Weirum Justice Mosk wrote that

the verdict in plaintiff's favor here necessarily embraced a finding that decedent was exposed to a foreseeable risk of harm. It is elementary that our review of this finding is limited to the determination whether there is any substantial evidence, contradicted or uncontradicted, which will support the conclusion reached by the jury. ${ }^{120}$

It is widely acknowledged that "any rule of substantive law or procedure which enlarges the jury's theoretical sphere tends to extend hability ...."121 Both in its holding and in its doctrinal innovation, Weirum does precisely that.

119. See, e.g., Adams v. Southern Pac. Transp. Co., 50 Cal. App. 3d 37, 123 Cal. Rptr. 216 (3d Dist. 1975). In Adams, defendant railroad's trainload of military bombs exploded. Plaintiff, an einployee of a plant destroyed by the railroad, sought recovery from defendant for lost einployment and wages. Justice Friedman, for the court of appeal, held that existing California precedent barred recovery and that his court could not appropriately disregard that precedent. In an opinion strikingly similar to Weirum, however, he wrote that the new California approach to duty and foreseeability suggested that the traditional mle barring recovery "may be ripe for renunciation or limitation." Id. at 41, 123 Cal. Rptr. at 218. The California Supreme Court demied a hearing in Adams. 123 Cal. Rptr. 216 (1975).

120. $15 \mathrm{Cal}$. $3 \mathrm{~d}$ at 46,539 P.2d at $39-40,123 \mathrm{Cal}$. Rptr. at $471-72$.

121. 2 HARPER \& JAMES, supra note 13, at 894. Of course, the Weirum approach does not abrogate all duty limitations. For example, in Nipper v. California Auto. Assigned Risk Plan, 19 Cal. 3d 35, 560 P.2d 743, 136 Cal. Rptr. 854 (1977), the court held, over Justice Tobriner's dissent, that the California Automobile Assigned Risk Plan and an insurance broker were not liable in tort for damages caused by an imcompetent driver whom they were instrumental in insuring. Significantly, the desirability of distributing accident losses through imsurance was seen as a reason to refuse to expand the mcidence of liability in this situation: "We think that to impose tort liability .. . would be to narrow rather than to broaden insurance coverage of California highway accidents . . . ." Id. at 49, 560 P.2d at 750, 136 Cal. Rptr. at 861 . 
In summary, the cases surveyed above show an unprecedented degree of judicial creativity aimed at increasing the incidence of liability and the spreading of losses by means of liability insurance. During the 1960 's and 1970's, the court changed the basis of liability from negligence to strict liability in the products liability area. At the same time, it eliminated doctrines that exempted defendants from negligence liability, and also refornulated negligence doctrine to ease the burdens of litigation for plaintiffs. Dean Prosser wrote in 1971 that the developinent of strict products liability during the preceding decade represented "the most rapid and altogether spectacular overturn of an established rule in the entire history of the law of torts."122 Writing of tort law generally, the 1977 edition of the Gregory, Kalven, and Epstein torts casebook called the period 1969 through 1977 "the eight inost eventful years in the entire history of tort law."123 These descriptions aptly cliaracterize the California tort cases of the 1960's and 1970's.

\section{II}

\section{DAMAges}

As the court expanded the imcidence of liability during the 1960's and 1970's, it also dealt witl dannages issues. Some cases raised clcar damages issues, such as whether to allow the per diem argument as to pain and suffering. ${ }^{124}$ These we shall call "explicit" damages cases. But the court also decided cases that at first do not appear to raise damages issues. The fornial issue nost often discussed im these "implicit" dainages cases was whether the plaintiff's allegations stated a cause of action. Some of these cases determined, for example, whether a tort action existed for loss of consortium; ${ }^{125}$ others defincd the parameters of recovery for einotional distress. ${ }^{126}$ Although these cases usually are analyzed as ones in which the court decided whether to expand further

122. W. Prosser, supra note 60, at 654 .

123. C. Gregory, H. Kalven, \& R. Epstein, Cases and Materials on Torts xxi (3d ed. 1977).

124. Beagle v. Vasold, 65 Cal. 2d 166, 417 P.2d 673, 53 Cal. Rptr. 129 (1966). Under the per diem method, the jury is asked to value one day's or one hour's pain and suffering and then to multiply by the number of umits plaintiff suffered.

125. Baxter v. Superior Court, 19 Cal. 3d 461, 563 P.2d 871, 138 Cal. Rptr. 315 (1977); Borer v. American Airlines, Inc., 19 Cal. 3d 441, 563 P.2d 858, 138 Cal. Rptr. 302 (1977); Rodrigucz v. Bethlehein Steel Corp., 12 Cal. 3d 382, 525 P.2d 669, 115 Cal. Rptr. 765 (1974).

126. See Justus v. Atchison, 19 Cal. 3d 564, 565 P.2d 122, 139 Cal. Rptr. 97 (1977), discussed at text accompanying notes 162-77 infra; Dillon v. Legg, $68 \mathrm{Cal}$. 2d 728, 441 P.2d 912, 69 Cal. Rptr. 72 (1968); Amaya v. Home Ice, Fuel \& Supply Co., 59 Cal. 2d 295, 379 P.2d 513, 29 Cal. Rptr. 33 (1963). 
the incidence of liability, ${ }^{127}$ recent "implicit" damages cases denying recovery can nore usefully be viewed as cases that reduce damages without entirely eliminating compensation through the tort system. In our view, these recent implicit damages cases do not indicate that the court is cutting back on the incidence of liability. Rather, they suggest a new conclusion regarding the court's handling since 1960 of tort damages issues. Through 1976 the court generally avoided decisions that would limit damage awards, and even developed damages doctrine so as to allow large awards. Beginning in 1977, however, the court retreated from its former position. The imphicit damages cases show a new concern for tort systein costs and represent a new response to damages issues, perhaps based on the court's perception of a current "cost crisis." 128

\section{A. Explicit Damages Issues}

\section{Position of the California Supreme Court}

While the court was radically increasing the incidence of defendant liability, it was also allowing juries and trial judges great latitude in determining the size of awards. The court virtually never reversed judgments on the ground that damages were excessive. The court's posture can be seen in its 1961 statement in Seffert v. Los Angeles Transit Lines:129

The amount of damages is a fact question, first committed to the discretion of the jury and next to the discretion of the trial judge on a motion for new trial . . . . As a result, all presumptions are in favor of the decision of the trial court . . . . An appellate court can interfere on the ground that the judgment is excessive only on the ground that the verdict is so large that, at first blush, it shocks the conscience and suggests passion, prejudice or corruption on the part of the jury. ${ }^{130}$

In addition to allowing juries great latitude, the court retained and expanded specific damages rules favorable to plaintiffs. Helfend $v$.

127. See, e.g., Horvitz, Justice Tobriner's Tort Decisions: A Reaffirmation of the Common Law Process, 29 Hastings L.J. 167, 169 (1977).

128. See text accompanying notes 140-214 infra.

129. 56 Cal. 2d 498, 364 P.2d 337, 15 Cal. Rptr. 161 (1961).

130. Id. at 506-07, 364 P.2d at 342, 15 Cal. Rptr. at 166 (citations omitted). The trial judge is allowed wide discretionary power, most effectively exercised through the techniques of additur and remittitur. Both of these techniques, as well as the granting of a new trial limited to damages, have been held not to deny the right to a jury trial. See, e.g., Jehl v. Southern Pac. Co., 66 Cal. 2d 821, 427 P.2d 988, 59 Cal. Rptr. 276 (1967) (use of additur is constitutional); Brewer v. Second Baptist Church, 32 Cal. 2d 791, 197 P.2d 713 (1948) (new trial limited to damages is constitutional); Davis v. Southern Pac. Co., 98 Cal. 13, 32 P. 646 (1893) (use of remittitur was proper). If the trial judge grants a new trial on the issue of excessive damages, however, "the presumption of correctness normally aecorded on appeal to the jury's verdict is replaced by a presumption in favor of the order." Neal v. Farmers Ins. Exch., 21 Cal. 3d 910, 932, 582 P.2d 980, 993, 148 Cal. Rptr. 389, 402 (1978) (citing Doolin v. Omnibus Cable Co., 125 Cal. 141, 57 P. 774 (1899)). 
Southern California Rapid Transit District, ${ }^{131}$ decided in 1970, reaffirmed the frequently criticized ${ }^{132}$ collateral source rule that prevents reduction of a plaintiff's recovery to refiect benefits actually received from another source, such as first-party health insurance. In Seffert, the court sanctioned pain and suffering awards that were much larger than pecuniary loss. ${ }^{133}$ In Beagle $v$. Vasold, ${ }^{134}$ the Court found reversible error in a trial judge's refusal to allow plaintiff's attorney to make the "per diem" argument concerning pain and suffering.

\section{Position of Justice Traynor}

Justice Traynor, the leader in the moveinent to expand hability, was frequently in disagreeinent with the majority of the court on damages issues. Justice Traynor dissented in Seffert on the issue of the propriety of the large pain and suffering award. ${ }^{135}$ In Beagle, he also disagreed with the inajority regarding the propriety of the per diem argument. ${ }^{136}$

These dissents were not isolated disagreements with the majority of the court. Rather, they were manifestations of Justice Traynor's fundamental disagreeinent about the proper role of damages once a tort systen 1 nioved past nineteenth century liability limitations to encompass the loss distribution premise. ${ }^{137}$ Justice Traynor realized that expansive liability theories entail additional costs. This recognition forined the premise of his position regarding damages: if reasonably adequate compensation is assured, curbs on inflationary damage eleinents sliould be imposed. ${ }^{138}$

Justice Traynor's Seffert dissent is a striking exainple of the application of his general dainages perspective to the issue of pain and suffering. Not only would he have found the jury's award to be excessive, but he was also skeptical of any award for pain and suffering. Justice Traynor thought that such damages were inappropriate in a tort system that is based on compensation and the distribution of losses through insurance:

131. 2 Cal. 3d 1, 465 P.2d 61, 84 Cal. Rptr. 173 (1970). See also Acosta v. Southern Cal. Rapid Transit Dist., 2 Cal. 3d 19, 465 P.2d 72, 84 Cal. Rptr. 184 (1970).

132. See, e.g., 2 HARPER \& JAMES, supra note 13, at $\$ 25.22$ (1968 Supp.); Fleming, The ColJateral Source Rule and Loss Allocation in Tort Law, 54 CALIF. L. REv. 1478 (1966); Note, Unreason in the Law of Damages: The Collateral Source Rule, 77 HARv. L. REv. 741 (1964).

133. See also Capelouto v. Kaiser Found. Hosp., 7 Cal. 3d 889, 500 P.2d 880, 103 Cal. Rptr. 856 (1972) (infant can recover for pain and suffering).

134. 65 Cal. 2d 166, 417 P.2d 673, 53 Cal. Rptr. 129 (1966).

135. 56 Cal. 2d at 509, 364 P.2d at 344, 15 Cal. Rptr. at 168 (Traynor, J., dissenting).

136. $65 \mathrm{Cal} .2 \mathrm{~d}$ at 183, 417 P.2d at 683, $53 \mathrm{Cal}$. Rptr. at 139 (Traynor, C.J., concurring and dissenting).

137. See Traynor, supra note 13 , at 376 .

138. Id. 
[Damages for pain and suffering] become increasingly anomalous as einphasis shifts in a inechanized society from ad hoc punishment to orderly distribution of losses through insurance and the price of goods or of transportation. Ultimately such losses are borne by a public free of fault as part of the price for the benefits of mechanization. ${ }^{139}$

Justice Traynor seldoin gained a majority for his damages perspective. Recent "imphicit" damages cases, however, may indicate a new approach to dainages issues by the court. Ironically, these cases reflect more of Justice Traynor's damages perspective than he was able to convince the court to accept while he was a justice.

\section{B. The "Implicit" Damages Issues}

Beginning in 1977, the court decided a number of cases that can best be understood as "implicit" damages cases. These cases show the court's concern, at times expressly articulated, over rismg tort costs. Their effect is to decrease damage awards and thus tort system costs. The first cases discussed suggest what we call a "family damages" doctrine, under which the recovery of a family unit is diminished but not eliminated. Then we discuss Walters $v$. Sloan, ${ }^{140}$ a case reaffirming and extending the "fireman's rule." Walters is analyzed as an extension of the implicit damages approach beyond the family unit. Next, we use the implicit damages concept to place in perspective important 1978 cases dealing with the doctrine of comparative neghigence. Finally, we analyze a group of cases whose goal is to increase the administrative efficiency of the tort system and thus to lower tort costs.

\section{The "Family Damages Doctrine"}

In 1977 the court decided three cases in which the formal issue was whether a substantive cause of action existed. In Borer v. American Airlines, Inc. ${ }^{141}$ and Baxter v. Superior Court, ${ }^{142}$ the court refused to recognize a cause of action for loss of parent-child consortiund; in Justus $v$. Atchison, ${ }^{143}$ the court refused to allow parents to maintain an action for the death of their unborn child. These cases can best be understood as implicit damages cases, simce their effect, as opposed to their formal holdings, is to decrease damage awards. Specifically, these cases in-

139. Seffert v. Los Angeles Transit Lines, $56 \mathrm{Cal}$. 2d at 511, 364 P.2d at 345, 15 Cal. Rptr. at 169 (Traynor, J., dissenting). But see Justice Traynor's views in State Rubbish Collectors Ass'n v. Siliznoff, $38 \mathrm{Cal}$ 2d 330, 240 P.2d 282 (1952) (mtentioual infliction of emotional distress). The logic of Justice Traynor's Siliznoff position suggests that distinct issues are presented by awards of punitive damages.

140. 20 Cal. 3d 199, 571 P.2d 609, 142 Cal. Rptr. 152 (1977).

141. 19 Cal. 3d 441, 563 P.2d 858, 138 Cal. Rptr. 302 (1977).

142. 19 Cal. 3d 461, 563 P.2d 871, 138 Cal. Rptr. 315 (1977)

143. 19 Cal. 3d 564, 565 P.2d 122, 139 Cal. Rptr. 97 (1977). 
volved factual patterns where the effect of the holdings unay have been to diminish, but not eliminate, recovery by the family unit. Moreover, under these decisions, the family unit may be fully compensated for all pecuniary losses; the diminution of damages may simply reduce the aniount recovered for nonpecuniary loss.

\section{a. Borer and Baxter}

The Borer and Baxter holdings were sounewhat surprising because only three years before, in Rodriguez v. Bethlehem Steel Corp. ${ }^{144}$ the court, in an opinion written by Justice Mosk and signed by Justice Tobriner, ruled that a niarried person whose spouse was neghigently injured by a third party had a cause of action for loss of consortium. In Rodriguez, the court rejected arguments that the damages were too speculative or renote and that allowing such damages would lead to unlimitcd hability. In holding that defendants owed a duty to the spouse, the court emphasized the eleunent of foreseeability. ${ }^{145}$ The importance of foreseeability in establishing a duty was reemphasized a year later in Weirum. ${ }^{146}$ Commentators predicted that recovery for loss of parent-child consortiun would be allowed and concluded that such an extension las "logical and sympathetic appeal."147

Despite the sunall conceptual step from Rodriguez to allowing dainages for loss of parent-child consortiun1, in Borer and Baxter the court - over vigorous dissents by Justice Mosk, the author of Rodriguez-refused to recognize such causes of action. Justice Tobriner, writing for the majority, rehed on three argunients. First, loss of consortiun is an intangible and nonpecuniary injury. As a result, damages are difficult to neeasure and can not truly coinpensate the victim for his loss. Second, the possibility of double recovery, or of a inultiplicity of suits, places an unjustifiable burden on the defendant. Third, Rodriguez is distinguishable because it rested in large part on the "impairinent or destruction of the sexual hife of the couple,"148 an element lacking in a parent's or child's suit for loss of consortium.

144. 12 Cal. 3d 382, 525 P.2d 669, 115 Cal. Rptr. 765 (1974).

145. "One who negligently causes a severely disabling injury to an adult may reasonably expect that the injured person is inarried and that his or her spouse will be adversely affected by that injury." Id. at 400,525 P.2d at 680,115 Cal. Rptr. at 776.

146. See text accompanying notes 111-14 supra.

147. Comment, The Child's Claim for Loss of Consortium Damages: A Logical and Sympathetic Appeal, 13 SAN Diego L. Rev. 231, 236 (1975); See Love, Tortious Interference with the Parent-Child Relationship: Loss of an Injured Person's Society and Companionship, 51 IND. L.J. 590 (1976).

148. Borer v. American Airlines, Inc., 19 Cal. 3d at 448, 563 P.2d at 863, 138 Cal. Rptr. at 307 (quoting Rodriguez v. Bethlehem Steel Corp., 12 Cal. 3d at 405, 525 P.2d at 684, 115 Cal. Rptr. at 780). 
These arguments are weak. ${ }^{149}$ Loss of parent-child consortium is a foreseeable injury in the same sense that loss of spousal consortium is. Valuation of damages for loss of parent or child consortium is no more difficult than assessimg other types of intangible imjuries, such as paim and suffering, emotional distress, elements of wrongful death damages, and loss of spousal consortium. As for the problems of double recovery and inultiple suits, the Rodriguez court, when faced with similar arguments, found that the problems were susceptible to judicial solution in precisely the manner rejected by the Borer and Baxter majority-jomder and appropriate jury instructions. ${ }^{150}$ Because a victim necessarily has only one spouse, the Rodriguez court was not faced with the identical question of multiple suits. Justice Mosk in his Borer dissent, however, found this concern to be unwarranted: "Upon reflection, it will be seen that [minor] children inevitably comprise a much more limited class than spouses." 151 Finally, the majority's attempt to distinguish Rodriguez on the ground that it was based on impairment or destruction of the couple's sexual life fails to account for the fact that "a husband or wife of advanced years suffers a no less compensable loss of conjugal society when his or her lifetime companion is grievously injured by the negligence of another." 152 In fact, Rodriguez expressly stated that the wife's personal loss is not limited to her sexual rights, and reasoned that the nonsexual loss suffered by a spouse is at least as great as the sexual loss. ${ }^{153}$

Although the Borer court struggled to find a logically defensible rationale to support the line that it drew between compensable and noncompensable imjuries, it was forced to admit candidly that

our decision must take into account considerations in addition to logical symmetry and sympathetic appeal . . . . [N]ot every loss can be made compensable in money dainages, and legal causation must terminate somewhere. In delineating the extent of a tortfeasor's responsibility for damages . . . the courts must locate the line between hability and nonliability at some point, a decision which is essentially poitical. ${ }^{154}$

149. See Note, The Supreme Court of California 1976-1977, 66 CAL1F. L. REv. 138, 437 (1978).

150. Rodriguez v. Bethlehem Steel Corp., 12 Cal. 3d at 406, 525 P.2d at 685, 115 Cal. Rptr. at 781. So strong was the Rodriguez court's rejection of the double recovery argument, that it labelled it "fallacious," "fictional," and a "bogey" - "merely a convenient chiche" for denying liability. Id. at 404, 525 P.2d at 683, 115 Cal. Rptr. at 779.

151. 19 Cal. 3d at 458, 563 P.2d at 869, 138 Cal. Rptr. at 313 (Mosk, J., dissenting).

152. Id. at 456, 563 P.2d at 868, 138 Cal. Rptr. at 312 (Mosk, J., dissenting).

153. 12 Cal. 3d at 405-06, 525 P.2d at 684, 115 Cal. Rptr. at 780.

154. 19 Cal. 3d at 446-47, 563 P.2d at 862, 138 Cal. Rptr. at 306 (quoting Suter v. Leonard, 45 Cal. App. 3d 744, 746, 120 Cal. Rptr. 110, 111 (2d Dist. 1975)). In his Borer dissent, Justice Mosk characterized the majority's loldinig as "a purely discretionary exercise of the judicial power to limit the potential liability of common law tortfeasors." Id. at 459, 563 P.2d at 870, 138 Cal. Rptr. at 314 (Mosk, J. dissenting). 
Nevertheless, the Borer and Baxter results are puzzling if viewed as policy decisions limiting the imposition of liability, for they seem to be exceptions to the trend of the court over the past twenty years toward creating new avenues of tort recovery.

But Borer and Baxter nay also be viewed as damages cases which inerely lessen tort recovery by the family unit for intangible, nonpecuniary loss. When analyzed as "implicit damages" cases, Borer and Baxter do not contradict the trend that was set by cases that expanded the incidence of liability; rather Borer and Baxter indicate the court's new nood concerning dainages. ${ }^{155}$

The key to this reading of the cases is contained in passages from the Borer opinion. The court enphasized that recovery was sought for intangible, nonpecuniary losses for which plaintiffs can never truly be coinpensated. In this context, the court demonstrated a new responsiveness to the perceived problem of rising tort costs: "We cannot ignore the social burden of providing damages for loss of parental consortiuni inerely because the inoney to pay such awards comes initially from the 'negligent' defendant or his insurer."156 The court then expressly noted the undesirable effects of rising tort costs: "Reahistically the burden of paynient of awards for loss of consortiuin inust be borne by the public generally in increased insurance premiums or otherwise, in the enhanced danger that accrues from the greater number of people who inay clioose to go without any insurance." 157

The Borer and Baxter holdings limit total family damages, even though, formally, the decisions eliminated a cause of action of a particular family nember. Each case involved a minor child living with a parent. Since the initially injured parent or child, on proof of negligence, still had a cause of action against the defendant, the fainily as an economic unit suffered a reduction, but not an elimination of damages. Indeed, Justice Tobriner suggested precisely this analysis in Borer:

The asserted social need for the disputed cause of action [by a child for loss of parental consortium] may well be qualified, at least in terms of the family as an economic umit, by the practical consideration recog-

155. The implicit damages perspective does not remove the tension between the holding in Rodriguez and the holdings in Borer and Baxter. A shift toward greater cost and damages consciousness is bound to begin with decisions that draw practical, if not always logically compellimg, lines. See generally O.W. Holmes, The Common LAw 5 (Howe ed. 1963). The California Citizens' Commission, struck by tension, went so far as to suggest that Borer and Baxter are temporary aberrations and are unlikely to remain law. CALIFORNIA CITIZENS' CoMmission, Righting THE LIABILITY BALANCE: REPORT OF THE CALIFORNIA CITIZENS' COMMISSION ON TORT REFORM 65 (1977) [heremafter cited as Citizens' CoMmission].

156. $19 \mathrm{Cal} .3 \mathrm{~d}$ at $447,563 \mathrm{P} .2 \mathrm{~d}$ at $862,138 \mathrm{Cal}$. Rptr. at 306.

157. Id. Compare the court's earlier approach in cases such as Rowland v. Christian, 69 Cal. 2d 108, 443 P.2d 561, 70 Cal. Rptr. 97 (1968), in which it assumed that higher insurance rates caused by grcater liability could easily be passed on. See text accompanying note 63 supra. 
nized by many of the cases on the point that reflection of the consequential disadvantages to children of injured parents is frequently found in jury awards to the parents on their own claims under existing law and practice. ${ }^{158}$

Paradoxically, Justice Tobriner dissented, along with Justice Mosk, when the court used the family damages concept in the 1974 case, Steed v. Imperial Airlines, ${ }^{159}$ in which the court. refused to allow a nonadopted stepchild to recover under California's wrongful death statute. ${ }^{160}$ The majority stressed a narrow reading of the word "heirs" in the statute to deny recovery. In addition to this statutory argument, the court explicitly adopted a "family damages" approach:

Although we commend those who express concern because of the situation in which the mimor plamtiff has been innocently placed, it is fair to note that that minor is a dependent of her inother who survives and, we inay presume, has been coinpensated for the wrongful death of the decedent, her husband. ${ }^{161}$

Justice Tobriner's Borer opinion breathes new life into this approach.

\section{b. Justus}

Justus v. Atchison, ${ }^{162}$ a decision written by Justice Mosk and handed down only one month after Borer and Baxter, also supports this analysis. One issue in Justus involved negligent infliction of emotional distress. To understand this aspect of Justus, one inust start with the 1968 case of Dillon v. Legg, ${ }^{163}$ in which the court, in an opinion by Justice Tobriner, with Chief Justice Traynor dissentimg, allowed a inother who was not herself in any physical danger to sue for her emotional distress that resulted froin observing her daughter being struck by an automobile. ${ }^{164}$ The court limited its holding to cases in which the "plaintiff suffered a shock which resulted in physical injury"165 and

158. 19 Cal. 3d at 448,563 P.2d at 863,138 Cal. Rptr. at 307 (quoting Russell v. Salem Transp. Co., 61 N.J. 502, 507, 295 A.2d 862, 864 (1972)).

159. 12 Cal. 3d 115, 524 P.2d 801, 115 Cal. Rptr. 329 (1974).

160. Cal. Civ. Proc. Code $\$ 377$ (West Supp. 1978). Justice Tobriner appears to be alone on the court in the view that California should follow the lead of other jurisdictions and develop nonstatutory wrongful death actions. See Justus v. Atchison, $19 \mathrm{Cal}$. 3d 564, 586, 565 P.2d 122, 136, 139 Cal. Rptr. 97, 111 (1977) (Tobriner, Acting C. J., concurring).

161. 12 Cal. $3 d$ at 126,524 P.2d at 808,115 Cal. Rptr. at 336.

162. 19 Cal. 3d 564, 565 P.2d 122, 139 Cal. Rptr. 97 (1977).

163. $68 \mathrm{Cal}$. 2d 728, 441 P.2d 912, 69 Cal. Rptr. 72 (1968) (overruling Amaya v. Home Ice, Fuel \& Supply Co., 59 Cal. 2d 295, 379 P.2d 513, 29 Cal. Rptr. 33 (1963)).

164. Justice Tobriner's Dillon opinion sharply contrasts with his Borer opinion. In the former, with regard to the possibility of a "flood of litigation," Justice Tobriner wrote: "Courts are responsible for dealing with cases on their merits, whether there be few suits or many; the existence of a multitude of claims merely shows society's pressing need for legal redress." $68 \mathrm{Cal}$. $2 \mathrm{~d}$ at 735 n.3, 441 P.2d at 917 n.3, 69 Cal. Rptr. at 77 n.3. Our analysis of the Dillon/Justus issue as a damages question suggests one reason for Justice Traynor's Dillon dissent.

165. Id. at 740, 441 P.2d at 920, 69 Cal. Rptr. at 80. See also Capelouto v. Kaiser Found. 
listed three factors to determine whether subsequent cases fell within Dillon's ruling:

1) Whether plaintiff was located near the scene of the accident as contrasted with one who was a distance away from it.

2) Whether the shock resulted froin a direct emotional impact upon plaintiff from the sensory and contemporaneous observance of the accident, as contrasted with learning of the accident from others after its occurrence.

3) Whether plaintiff and the victim were closely related, as contrasted with an absence of any relationship or the presence of only a distant relationship. ${ }^{166}$

Justice Mosk's opinion in Justus narrows the Dillon holding, with Justice Tobriner's express approval. In Justus, plaintiff was a father who liad been present at the stillbirth of his child-a stillbirth that was alleged to have been caused by the neghigence of defendant doctors. The court ruled that there was no Dillon cause of action. It einphasizcd that Dillon required that the shock to the plaintiff "result from a 'direct emotional impact' on the plaimtiff caused by 'sensory and contemporaneous observance of the accident' . . ."167 In Justus, this requirement was not met because, although plaintiff was present at the death of the fetus, "that event was by its very nature hidden from his contemporaneous perception . . . ."168 The plamtiff witnessed disturbing events in the operating room, but the significant emotional "impact derived not from what he saw and heard during the attempted delivery, but froin what he was told after the fact."169 The court's rationale at best provides slim grounds on which to distmguish Dillon. ${ }^{170}$ It is highly unrealistic for the court to parcel up a continuous series of events into discrete moments. If the court takes its language seriously, in future cases it would have to look to the exact moment of imjury and the exact position of the parties to determine whether the "sensory and contem-

Hosps., 7 Cal. 3d 889, 500 P.2d 880, 103 Cal. Rptr. 856 (1972). One may wonder to what extent this requirement inerely instructs plaintiff's attorneys to be more inventive in documenting physical inanifestations of emotional distress. Cf. Alcorn v. Anbro Eng'r, Inc., 2 Cal. 3d 493, 468 P.2d 216, 86 Cal. Rptr. 88 (1970) (requirements for proof of physical imjury are dispensed with for the tort of intentional infliction of emotional distress).

166. $68 \mathrm{Cal} .2 \mathrm{~d}$ at 741, 441 P.2d at 920,69 Cal. Rptr. at 80 . All but two courts of appeal eases in California have involved a plaintiff who witnessed a close relative's physical injury. Two cases have allowed a "Dillon" cause of action in other situations, however. See Vescovo v. New Way Enterprises, Ltd., 60 Cal. App. 3d 582, 130 Cal. Rptr. 86 (2d Dist. 1976) (upholding children's Dillon action against newspaper that ran a sexual ad featuring their mother's phone number); Jarchow v. Transanerica Title Ins. Co., 48 Cal. App. 3d 917, 122 Cal. Rptr. 470 (1975) (allowing Dillon recovery for title insurance company's failure to list easement on title report).

167. 19 Cal. $3 \mathrm{~d}$ at 584,565 P.2d at 135,139 Cal. Rptr. at 110.

168. Id.

169. Id. at $585,565 \mathrm{P} .2 \mathrm{~d}$ at $136,139 \mathrm{Cal}$. Rptr. at 111 .

170. Cf. Krouse v. Grahain, 19 Cal. 3d 59, 562 P.2d 1022, 137 Cal. Rptr. 863 (1977), which inore broadly interprets the saine requirement. 
poraneous observance" requirement has been satisfied. Such conceptual rigidity is too much of a departure from the court's style in the tort area over the past twenty years to be considered a determining factor in the decision. Similarly, foreseeability does not provide the needed rationale. If foreseeability of harm-which the court relied on in Dillon-has any common sense meaning, it would certainly be foreseeable that a father watching the stillbirth of his child would suffer einotional distress. If these rationales are unconvincing and the Court continues to stand by Justus on this issue, ${ }^{171}$ one could well wonder whether more subtle factors were involved in the decision.

The desire of the court to limit family damages provides a more satisfactory explanation of the Justus holding. ${ }^{172}$ In inost cases decided by the California courts of appeal that deal with negligent infliction of emotional distress, the plaintiff was a close relative who lived with the party whose injury he witnessed. ${ }^{173}$ Thus, in practice, the prime use of Dillon has been to compensate members of a household when other inembers of that household have been mjured. Moreover, the predominant element of damages under a Dillon cause of action is likely to be for intangible, nonpecuniary loss. Thus Justus, like Borer and Baxter, can be read as limiting family damages rather than eliminating an imdividual's causes of action. Even in Justus, the mother would have a cause of action upon proof of injuries to her caused by the neghigent delivery. This analysis does not legitimize the Justus result, ${ }^{174}$ but inerely points out that, in many cases, the difference between Dillon's

171. In 1978 the court expressly endorsed its Justus holding: "We held in Justus that Dillon requires more than mere physical presence: . . . the shock must also result from a direct emotional impact on the plaintiff caused by sensory and conteinporaneous observance of the accident." Hoyem v. Manhattan Beach City Sch. Dist., 22 Cal. 3d 508, 585 P.2d 851, 150 Cal. Rptr. 1 (1978) (Tobriner, J.) (mother had no Dillon cause of action for emotional and physical injuries suffered as a consequence of seeing her son in the hospital several hours after the accident). For a discussion of other aspects of Hoyem, see note 248 infra.

172. With hindsight, the seeds of the family damages doctrine can be found in Dillon itself. In discussing the effect on a nother's right to recovery if an injured child is proved to have been contributorily negligent, the court wrote:

If any such defense is sustained and defendant found not hable for the death of the child because of the contributory negligence of the mother, sister or child, we do not believe that the mother or sister should recover for the einotional trauma which they allegedly suffered. In the absence of the primary hability of the tortfeasor for the death of the child, we see no ground for an independent and secondary hability for claims for injuries by third parties.

$68 \mathrm{Cal} .2 \mathrm{~d}$ at 733, 441 P.2d at 916, 69 Cal. Rptr. at 76. The negligent infliction of emotional distress is thus to be viewed as a derivative action. See generally Rintala (now Brudno), The Supreme Court of California 1968-1969-Foreword: "Status" Concepts in the Law of Torts, 58 CALIF. L. REv. 80, 105-19 (1970). Of conrse, the court's statement was made prior to Li v. Yellow Cab Co., 13 Cal. 3d 804, 532 P.2d 1226, 119 Cal. Rptr. 858 (1975). See text accompanying notes 74-77 supra. Thus, a child's negligence today may reduce, but not bar, a parent's recovery.

173. See note 166 supra.

174. For criticisin of Justus, see text following note 230 infra. 
expansiveness and Justus' restrictiveness relates more to a limitation of total family recovery, than to a restriction of the family unit's ability to distribute any of its losses.

The same interpretation can be made of the second Justus holding that there is no cause of action under the wrongful death statute for the death of a fetus (despite the fact that the "weight of authority" recognized the cause of action). Justice Mosk, writing for the court, reasoned that the legislature did not intend to provide a cause of action for the wrongful death of a stillborn fetus. Justice Tobriner concurred in this result, but not in the court's reasoning. Citing Borer, he characterized the loss in this situation as "a wholly intangible injury to plaintiffs for which any monetary recovery can provide no real compensation." 175 He concluded that "since this court decided to reject the asserted cause of action for the wrongful death of a fetus-as I believe it should-it inust rest that decision on reasons of policy similar to those discussed in Borer." 176 Whether or not one agrees with Justice Tobriner's analysis-and Justice Mosk presumably would not, as shown by his dissents in Borer and Baxter-it can at least be said that the harshness of the Justus result may often be partially ameliorated by the existence of alternate avenues of recovery for the family unit, ${ }^{177}$ and that this fact unay have influenced the court. The discussion of Borer and Baxter as family damages cases is thus applicable to the wrongful death holding of Justus.

In sum, the family damages concept is useful in understanding the court's holdings in Borer, Baxter, and Justus. It also indicates why the court continued along its familiar path of expanding liability in the contemporaneous incidence of liability cases. Barker, Cooper, and Coulter are dramatic examples of this phenomenon. Coulter v. Superior Court, ${ }^{178}$ for example, extended hability to noncommercial suppliers of alcoholic beverages. Because the issue was perceived to be the incidence of hability, the court adopted the Weirum emphasis on foreseeability estabhshing duty, and stressed the "fundamental principle of California law that a person is hable for the foreseeable injuries caused by his failure to exercise reasonable care." ${ }^{179}$ In sole dissent, Justice

175. 19 Cal. 3d at 586, 565 P.2d at 136, 139 Cal. Rptr. at 111. (Tobriner, Acting C.J., concurring).

176. Id. at 586-87, 565 P.2d at 137, 139 Cal. Rptr. at 112 (Tobriner, Acting C.J., concurring). See also text accompanying notes 144-61 supra.

177. Cf. Note, The Supreme Court of California 1976-1977, 66 CALlF. L. REv. 137, 429 (1978) (characterizing the Justus holding as "logically defensible . . . [but seemingly] unjust"). As in Borer and Baxter, the seeming injustice of the Justus result can be explained, if not justified, by the family damages perspective.

178. 21 Cal. 3d 144, 577 P.2d 669, 145 Cal. Rptr. 534 (1978). See text accoinpanyimg notes 8389 supra.

179. Id. at 152,577 P.2d at 674,145 Cal. Rptr. at 539. 
Clark argued that this holding is inconsistent with the court's attitude in Borer and Baxter. But the cost consciousness of Borer and Baxter is absent in the inajority opinion. Indeed, the inajority wrote cryptically that "we may assume that insurance coverage (doubtless increasingly costly) will be made available to protect the social host from civil hability in this situation." 180 The family damages perspective explains the different approaches and results in incidence of hability cases in contrast to Borer, Baxter, and Justus.

\section{Beyond the Family Damages Doctrine: Walters v. Sloan}

The 1977 "fireman's rule" case, Walters $v$. Sloan, ${ }^{181}$ is a fourth example of the court's implicit damages approach, and demonstrates the usefuhress of the implicit damages concept as a tool for understandimg otherwise eniginatic California Supreme Court decisions. In Walters, the court expressly adopted a damages analysis and extended it beyond the family unit. The tort recovery of a family unit is not merely reduced. Rather, an entire class of potential plaintiffs is demed tort recovery.

In Walters the court, with only Justice Tobriner in dissent, reaffirmed the so-called "fireman's rule," which "provides that neghigence in causing a fire furnishes no basis for liability to a professional fireman injured fighting the fire," 182 and extended the rule to police officers. The court based its reaffirmation of the rule on two grounds. First, it found the rule to be based, in part, on the principle that "one who has knowingly and voluntarily confronted a hazard cannot recover for injuries sustained thereby." "183 The court wrote that this "principle" is recognized in a variety of doctrines, including assumption of the risk. Thus, Walters inight be read as a revival of the almost moribund doctrine of the assumption of the risk. The court stated that a plaintiff is totally barred from recovery when, "fully aware of the hazard created by defendant's negligence, [he] voluntarily confronts the risk for compensation." "184 But read this way, Walters would stand in stark contrast to twenty years of California tort law. It would be a case which limits

180. Id. at 153, 577 P.2d at 674,145 Cal. Rptr. at 539. Justice Tobriner joined the court's opinion in Coulter. Indeed, earlier in the year he wrote an opinion that also extended dram shop liability. Ewing v. Cloverleaf Bowl, 20 Cal. 3d 389, 572 P.2d 1155, 143 Cal. Rptr. 13 (1978) (allowing suit by intoxicated, injured customer or his estate). For Justice Tobriner, the einphasis on foreseeability controls in the incidence of liability cases. The cost consciousness of Borer and Baxter is absent from his opinion, although Justice Clark, dissenting in Ewing, pointedly calls Borer to the court's attention. Id. at $411-12,572$ P.2d at 1167,143 Cal. Rptr. at 26.

181. 20 Cal. 3d 199, 571 P.2d 609, 142 Cal. Rptr. 152 (1977).

182. Id. at 202, 571 P.2d at 610,142 Cal. Rptr. at 153. For criticisin of the decision, see text accoinpanying notes 231-36 infra.

183. Id. at 204, 571 P.2d at 612, 142 Cal. Rptr. at 155.

184. Id. 
the incidence of hability. Given the antipathy of the court toward limiting the incidence of liability in general and the court's reluctance to accept the defense of assumption of the risk, Walters is best read not as a revival of assumption of the risk. ${ }^{185}$ Rather, its reaffirmation of the "fireman's rule" can be explained by another rationale.

The court's second reason for retaining the fireman's rule was "public policy". On close examination, this justification turns out to be an implicit damages argument. The cost consciousness of the implicit damages approach is apparent. The court wrote that it would be too burdensome to charge a negligent defendant with this liability and that such actions would burden our courts with litigation. Furthermore, the compensation of policemen and firemen reflects the risks they take. "In addition to the usual medical and disability benefits ordinarily provided all employees covered by the Workers' Compensation Act, firemen and pohicemen are provided special benefits. . . . [T] he special disability pensions and other benefits payable to firemen and policemen substantially exceed ordinary disability compensation benefits." "186 This is an imphicit damages rationale. Firemen and policemen are already adequately compensated for injuries. Accordingly, as a matter of damages law, the demal of tort recovery is justified.

Unlike the other 1977 implicit damages cases, however, Walters is not a family damages case. The plaimtiff in Walters was denied any compensation through the tort system. Thus, Walters goes further than Borer, Baxter, and Justus in its use of the implicit damages approach, and its implications are potentially far-reaching. For exanıle, this case can be seen as challenging the premises underlyimg the collateral source rule. Plaintiff is denied tort recovery because of perceived sufficient compensation from other sources.

\section{Comparative Fault from a Damages Perspective}

The damages perspective is also useful in understandimg two major cases decided by the court im 1978 concerning the doctrine of comparative neghigence (or fault). In Daly v. General Motors Corp., ${ }^{187}$ the court, with Justice Tobriner concurring in a 4-3 split, held that the de-

185. See text accompanying notes 78-82 supra. Even the quoted language from Walters states a proposition that a inajority of the court would be unlikely to accept as apphied to persons other than firemen or policemen. Justice Tobriner mentions highway workers "whose jobs obviously subject them to the 'inherent risk' of being imjured by a negligent driver." $/ d$. at 213,571 P.2d at 617, 142 Cal. Rptr. at 160 (Tobriner, Acting C.J., dissenting). California cases have regularly allowed recovery in this situation. Even closer analogies to policemen would be paramedics, ambulance drivers, and tow truck operators. Sucli examples undermine a reading of Walters as a reemergence of the assumption of risk defense.

186. Id. at 205-06, 571 P.2d at 612-13, 142 Cal. Rptr. at 155-56.

187. 20 Cal. 3d 725, 575 P.2d 1162, 144 Cal. Rptr. 380 (1978). 
fense of comparative fault extends to strict products liability. Justice Mosk, in an angry dissent, wrote that "[t]le pure concept of products liability so pridefully fashioned and nurtured by this court for the last decade and a lialf is reduced to a shambles." ${ }^{188}$ Daly, one could argue, turns away from the principles of strict liability and the goal of distributimg losses. But Daly is better analyzed from a damage perspective, especially in light of the other major 1978 comparative negligence case, American Motorcycle Association v. Superior Court. ${ }^{189}$

As discussed previously, in 1975, the court in $\mathrm{Li}$ v. Yellow Cab Co. ${ }^{190}$ abolished the traditional common law doctrine of contributory negligence and adopted a system of pure comparative neghigence. We have pointed out that $L i$ could be seen as the abrogation of a rule that sometimes totally immunized negligent defendants and their insurers. $L i$, however, not only increases the incidence of liability. It is also a damages case since it diminishes recovery by negligent plamtiffs. ${ }^{191}$

In American Motorcycle, the court dealt with the implications of Li's comparative negligence rule in situations in which neghigence is alleged agamst more than one defendant. The court, in an opinion by Justice Tobriner, decided to retain the rule of joint and several liability, under which a concurrent tortfeasor is liable for the total amount of damages, diminished only in proportion to plamtiff's neghigence. In his dissent, Justice Clark focused on the $L i$ statement that "liability for damage will be borne by those whose neghigence cause it in direct proportion to their respective fault."192 Justice Clark viewed the court's American Motorcycle opinion as being contrary to the $L i$ principle that defendants "fairly" should only be hable in proportion to their own negligence or fault. For example, a defendant who was only ten percent at fault may have to pay seventy percent of the loss to a plaintiff who was thirty percent at fault if the codefendant is unable to respond in damages.

The American Motorcycle holding and rationale emphasized the court's commitment to expand the incidence of liability and to further

188. Id. at 757, 575 P.2d at 1181, 144 Cal. Rptr. at 399 (Mosk, J., dissenting).

189. $20 \mathrm{Cal}$. 3d 578, 578 P.2d 899, 146 Cal. Rptr. 182 (1978). For a discussion of the issues raised by the American Motorcycle decision, see Levy, Pure Comparative Negligence: Set-Ofs, Multiple Defendants and Loss Distribution, 11 U.S.F. L. REv. 405 (1977).

190. 13 Cal. 3d 804, 532 P.2d 1226, 119 Cal. Rptr. 858 (1975). See text accompanying notes 74-77 supra.

191. Some personal injury attorneys opposed enactment of comparative negligence statutes precisely because they were "alarmed at the prospect of diminished verdicts and correspondingly lower fees." W. ProsSER, supra note 60, at 438. Presumably, they felt that juries ignored shight plaintiff negligence under the harsh contributory neghigence rule, but would not hesitate to reduce damages under a comparative neghigence rule.

192. $20 \mathrm{Cal} .3 \mathrm{~d}$ at 608, 578 P.2d at 919, $146 \mathrm{Cal}$. Rptr. at 201 (Clark, J., dissenting) (quoting Li v. Yellow Cab Co., 13 Cal. 3d at 813, 532 P.2d at 1232, 119 Cal. Rptr. at 864). 
loss distribution. The "fairness to defendants" argument was dwarfed by these goals: "from a realistic standpoint, we think that [the] suggested abandonment of the joint and several liability rule would work a serious and unwarranted deleterious effect on the practical ability of negligently injured persons to receive adequate compensation for their mjuries." "193 Joint and several liability was needed precisely because some defendants may be unable to respond in damages:

One of the principal by-products of the joint and several hability rule is that it frequently permits an injured person to obtain full recovery for his injuries even when one or more of the responsible parties do not have the financial resources to cover their hability . . . . The $L i$ decision does not detract in the shightcst froin this pragmatic policy determination. ${ }^{194}$

Thus the court remaimed steadfast in its commitment to the pragmatic policy determinations that it has so often stated. In addition, another holding of American Motorcycle showed similar commitment to expanding liability and distributing losses. The court held "that a plaintiff's recovery from nonsettling tortfeasors should be diminisled only by the amount that the plaintiff lias actually recovered in a good faitl settlement, rather than by an amount measured by the settling tortfeasor's proportionate responsibility for the injury." 195

193. 20 Cal. 3d at 590, 578 P.2d at 906, 146 Cal. Rptr. at 189 (Tobriner, J.).

194. Id.

195. Id. at 604, 578 P.2d at 916, 146 Cal. Rptr. at 199.

No such conflict between "fairness" and loss distribution arose with regard to another issue in American Motorcycle-the status of the statutory right of contribution and the common law doctrine of equitable indemnity after $L i$. In this context, the court was willing to create a new doctrine to increase fairness. Contribution allowed the pro rata apportionment of loss among joint tortfeasors in certain circumstances. The doctrine of equitable indemnity, when applicable, imvolved shifting entirely a loss froin one tortfeasor to another. To aehieve the objective of fairness to defendants, the court held that the "current equitable indemnity rule should be modified to permit a concurrent tortfeasor to obtain partial indemnity from other concurrent tortfeasors on a comparative fault basis." Id. at 598, 578 P.2d at 912,146 Cal. Rptr. at 195 . The court labelled this new doctrine "comparative indemnity." To effectuate this new right, the court held that a defendant may seek indemnification from a previously unnamed party by cross complaimt. Possible conflict with the loss distribution goal, however, is lessened by allowing the plaimtiff to enter into a "good faith" settlement that would release the impleaded party from liability to the other defendant. The plaintiff thus can prevent his case from becoming needlessly complex.

In Safeway Stores, Inc. v. Nest-Kart, 21 Cal. 3d 322, 579 P.2d 441, 146 Cal. Rptr. 550 (1978), the court held, in an opinion by Justice Tobriner, that "the comparative indemnity doctrine, recognized in American Motorcycle as a permissible basis for apportioming liability among multiple negligent tortfeasors, may also be applied to apportion liability when . . . the liability of one or more defendants derives froin principles of strict liability." Id. at 328, 579 P.2d at $444,146 \mathrm{Cal}$. Rptr. at 553 (einphasis in original). The court wrote that "fairness and other tort policies, sueh as deterrence of dangerous conduct or encouragement of accident-reducing behavior, frequently call for an apportionment of liability among inultiple tortfeasors." Id. at 330, 579 P.2d at 445, 146 Cal. Rptr. at 554. Significantly, these considerations were employed in a context that did not affect the loss distribution goal, which the court recoguized as being "one of the principal social policies served by product liability doctrine." $I d$. 
American Motorcycle is helpful in understanding the Daly holding that the defense of comparative fault extends to strict products liability. American Motorcycle aptly illustrates that the court will give weight to "fairness" considerations only where the loss distribution policy is not impaired thereby. Thus, the fact that Daly introduces coinparative fault to strict products liability does not necessarily signal a retreat froin the expansion of the incidence of liability or the loss distribution goal. Indeed, the practical effect of Daly-as opposed to its doctrinal basis-is to reduce the size of damage awards in products cases, ratler than totally to bar plaintiff recovery. Thus, Daly does not reduce the incidence of liability. ${ }^{196}$ Significantly, the Barker defect case, decided within months of Daly, reemphasized the court's determination to expand the incidence of liability in products cases. ${ }^{197}$ Morcover, in practice, a large percentage of the award in many products liability actions represents coinpensation for intangible losses such as pain and suffering. In terms of actual plaintiff recovery, then, Daly's reduction of damages will often affect only the recovery for such losses, leaving a plaintiff's recovery for tangible loss untoucled. ${ }^{198}$ Finally, the court in Daly expressly endorsed the Escola loss distribution goal ${ }^{199}$ and then wrote that under its holding the "cost of compensating the victim of a defective product, albeit proportionately reduced, remains on defendant manufacturer, and will, through him, be 'spread among society." "200 Thus Daly, like Borer, Baxter, and Justus, may be viewed as a damage case, consistent with the expanded incidence of liability and the loss distribution goal.

\section{Administrative Cost Issues}

Tort system costs may be reduced eitler by reducing the size of damage awards or by cutting the costs of administering the tort system. The court lias limited means of accomplishing the latter goal within the constraints of a traditional tort litigation structure. Nevertheless, the

196. It is possible, however, that evidence of plaintiff misconduct made admissible by Daly might lead juries to deny recovery totally even when the facts would not warrant such a result.

197. Barker v. Lull Eng'r Co., 20 Cal. 3d 413, 573 P.2d 443, 143 Cal. Rptr. 225 (1978). See text accompanying notes 37-42 supra.

198. Attorney fees may, however, radically change this arithmetic in individual cases. See text accompanying notes $245-46$ infra.

199. 20 Cal. 3d at 736, 575 P.2d at 1168,144 Cal. Rptr. at 386.

The Daly opinion saw its result as based, in part, on "fairness." Id. at 742, 575 P.2d at 1172, 144 Cal. Rptr. at 390. This rationale should be interpreted in light of American Motorcycle, where it is clear that "fairness to defendants" is subsidiary to the goal of ensuring adequate compensation. Daly correctly pays no heed to the claim that a contributory or comparative negligence defense is necessary to induce plaintiff safety. See Schwartz, Contributory and Comparative Negligence: A Reappraisal, 87 YALE L.J. 697, 703-21 (1978). Regarding the issue of whether defendant's safety incentives are lessened by reducing damages, see text accoinpanying note 241 infra.

200. 20 Cal. $3 d$ at 737, 575 P.2d at 1168-69, 144 Cal. Rptr. at 387 (emphasis added). 
court has rendered decisions that can be seen as attempts to reduce the costs of administering tort law.

One group of cases has given lawyers great leeway in binding their clients in the hitigation context. This may in the long run facilitate settleinent, avoid litigation, and thus reduce tort system costs. For example, in Tomerlin v. Canadian Indemnity Co., ${ }^{201}$ the court ruled that an insurance company was estopped froin arguing that an imsurance policy did not cover a particular occurrence after its attorney had made contrary representations. The court stated, "in cases involving defense by an insurance company the uniforn practice with regard to all questions involving the insurer is for the parties to the action to deal with the attorney retained by the insurer." 202 Thus, the court differentiated between insurance cases and other cases that had held that an attorney in an adversary proceeding lacks the authority to surrender his client's rights. The 1971 case of Navrides $v$. Zurich Insurance Co. ${ }^{203}$ also demonstrates the extent to which the court will go to encourage settlement procedures that will avoid litigation. In Navrides, a prior attorney for plaintiff, after settling with the insurance company, received a check jointly payable to himself and the client and then forged the client's naine to einbezzle the funds. Despite the clear hardship worked on plaintiff, who thus received no compensation for his injury, the court lield that, based on agency principles, the attorney's acts bound the injured plaintiff. The court emphasized its desire not to upset usually efficient metlods of settling personal injury cases, and held that attorney einbezzleinent is so rare that efficiency considerations outweighed plaintiff compensation in this particular case. ${ }^{204}$

Again, in Madden v. Kaiser Foundation Hospitals, ${ }^{205}$ the court used agency law to reach a result that it felt would help to avoid future tort litigation. In Madden, an einployer had provided a health plan and signed an agreennent to arbitrate disputes with the hospital. The employee liad not signed the agreeinent. The court held that the employee was bound by the arbitration agreement, and wrote that, "although the courts in the past regarded arbitration as an unusual and suspect procedure, they now recognize it as an accepted inethod of settlement of dis-

201. 61 Cal. 2d 638, 394 P.2d 571, 39 Cal. Rptr. 731 (1964).

202. Id. at 645,394 P.2d at 575, 39 Cal. Rptr. at 735 (emphasis in original).

203. 5 Cal. 3d 698, 488 P.2d 637, 97 Cal. Rptr. 309 (1971).

204. One can speculate that the plaintiff's bar generally was pleased with this decision. It is usual for insurance companies to draw checks payable to planitiff and plaintiffs attorney. Plaintiff's attorney usually will then have the chent endorse the check, endorse the check hinself, and deposit it in his trust account. The lawyer thus can assure payment of his fee by writing the client a check only for the amount of settlement less attorneys fees. After Navrides this common practice can continue.

205. 17 Cal. 3d 699, 552 P.2d 1178, 131 Cal. Rptr. 882 (1976). 
putes."206

Perhaps the most interestimg device that the court has used to encourage settlement rather than tort higation is the "bad faith" award against imsurance companies that fail to negotiate properly with parties injured by their insureds. Formally, these cases create a new tort, but their principal effect has been to encourage settlement in personal injury cases by requiring imsurance companies to act in good faith to settle claims rather than needlessly litigate.

The court's seminal case im this field is Crisci $v$. Security Insurance Co., ${ }^{207}$ decided in 1967. Crisci had a landowner's liability pohicy written by Security with a $\$ 10,000$ policy limit. Crisci's tenant DiMares was injured on the property. The company refused to accept DiMares' offer to settle for $\$ 9,000$. At a subsequent trial, DiMares received an award of $\$ 101,000$ against Crisci for her injuries. After the insurance company paid DiMares $\$ 10,000$, DiMares entered imto a settlement agreement with Crisci under which Crisci paid DiMares $\$ 22,000$, gave her an imterest in property, and assigned to her any cause of action that Crisci miglit have against the insurance company. DiMares then brought suit against Security in Crisci's name, asking for the original $\$ 101,000$ award (less $\$ 10,000$ already paid) and $\$ 25,000$ for Crisci's emotional distress caused by Security's refusal to settle.

On appeal, the supreme court rejected the insurance company's argument that its refusal to settle with DiMares was justified because liability of over $\$ 10,000$ was highly doubtful and held that in an insurance contract the insured is also purchasing legal protection through prompt settlement of claims. The imsurance company imphedly covenants to use good faith efforts to settle ${ }^{208}$ _the test of good faith being "whether a prudent insurer without policy limits would have accepted the settlement offer."209 Under this test, the court affirmed an award agamst the insurance company of $\$ 91,000$ for the excess judgment plus $\$ 25,000$ for emotional distress.

One can of course look at Crisci as beimg inerely one more case im

206. Id. at $702,552 \mathrm{P} .2 \mathrm{~d}$ at $1180,131 \mathrm{Cal}$ Rptr. at 884 .

207. 66 Cal. 2d 425, 426 P.2d 173, 58 Cal. Rptr. 13 (1967).

208. The court stated:

[T]here is more than a small amount of elementary justice in a rule that would require that, in this situation where the insurer's and the insured's interests necessarily conflict, the insurer, which may reap the benefits of its determination not to settle, should also suffer the detriments of its decision.

Id. at $431,426 \mathrm{P} .2 \mathrm{~d}$ at $177,58 \mathrm{Cal}$. Rptr. at 17.

209. Id. at $429,426 \mathrm{P} .2 \mathrm{~d}$ at $176,58 \mathrm{Cal}$. Rptr. at 16. The court declined to adopt here, or in the subsequent case of Johansen v. California State Auto. Ass'n, 15 Cal. 3d 9, 538 P.2d 744, 123 Cal. Rptr. 288 (1975), a rule akin to strict liability, whereby an insurance company always would be liable for any excess judgment whenever the insurer failed to accept a settlement offer within policy limits. 
which the court expanded the incidence of liability by creating a new tort. Its real significance, however, hes in its effect on insurance company settleinent practices. ${ }^{210}$ The "bad faith" action was not sanctioned because the court wished to force insurance companies to pay unore than their policy limits provide. Rather, it was designed to encourage insurance coinpanies to negotiate in good faith. ${ }^{211}$ This view of Crisci is supported by the court's treatinent of the dannages issue in insurance cases. The Crisci court itself extended existing law to allow dainages for einotional distress caused by the insurance coinpany's breach of contract. ${ }^{212}$ Additionally, in the 1978 case of Neal v. Farmers Insurance Exchange, ${ }^{213}$ the court allowed punitive dainages against an insurer whose behavior was found to be oppressive (as well as in "bad faith"). The court's aim in allowing these damages in the insurance contract context is to prevent conduct which leads to needless litigation of personal injury claims. Thus the "bad faith" cases represent the court's atteinpt to reduce tort systein costs by encouraging settleinent rather than hitigation. ${ }^{214}$

210. An apt analogy for this type of judicial activity may be drawn from the field of criminal law, where illegally obtaimed evidence is excluded in part to moderate law enforceinent practices. See Mapp v. Ohio, 367 U.S. 643 (1961).

211. Even dissents by judges inimical to the "bad faith" action have focused on the effect that these cases will have on future negotiations by insurance companies. See Neal v. Farmers Ins. Exch., 21 Cal. 3d 910, 942, 582 P.2d 980, 999, 148 Cal. Rptr. 389, 408 (1978) (Clark, J. dissenting).

212. Tort damages generally are unavailable to plaimtiffs suing for breach of contract. Exemplary damages are barred by statute, CAL. Civ. CodE $\$ 3294$ (West 1970), and recovery for emotional distress is disallowed by case law, Dryden v. Tri-Valley Growers, 65 Cal. App. 3d 990, 135 Cal. Rptr. 720 (1st Dist. 1977). The one exception to this bar is the Crisci recovery for insurer's breach of duty to act in "good faith" toward the insured party.

213. 21 Cal. 3d 910, 582 P.2d 980, 148 Cal. Rptr. 389 (1978).

214. In Murphy v. Allstate Ins Co., 17 Cal. 3d 937, 553 P.2d 584, 132 Cal. Rptr. 424 (1976), the court held that a third party claimant who had recovered a judgment against the insured for an amount in excess of the pohicy limits but who had not secured an assignment of the insured's cause of action could not sue the insurer for breach of the duty to settle. However, in Royal Globe lns. Co. v. Superior Court, 23 Cal. 3d 880, 592 P.2d 329, 153 Cal. Rptr. 842 (1979), the court, in an opinion by Justice Mosk with Justice Tobrimer concurring, held that a third party claimant may sue an insurer for unfair claims settlement practices which constitute violations of the Unfair Practices Act of the Insurance Code, CAL. INS. CODE $\$ 790.03$ (h) (West 1979), imcluding refusal by the insurer to atteinpt in good faith to effectuate a prompt, fair, and equitable settlement of plaintiff's claim although hability had become reasonably clear. The court distinguished Murphy on the ground that plaimtiff in Royal Globe did not rely upon the violation of the imsurer's duty to its insured to settle the claim; rather plaintiff rehed on the insurer's duty owed to plaimtiff under the Unfair Practices Act.

The Murphy opinion stated, "because a purely personal tort cause of action is not assignable in California, it must be concluded that damage for emotional distress is not assignable." $17 \mathrm{Cal}$. 3d at 942, 553 P.2d at 587, $132 \mathrm{Cal}$. Rptr. at 427. This statement should be disregarded. It is dictuin since no assignment had been alleged. As a matter of policy, it is unsound because its effect would be to reduce liability even for clear failures to negotiate in good faith, thus also reducing the economic incentives to bring these actions which police insurance negotiations. 


\section{ANALYSis of THE IMPlicit DaMages APPROACH}

California tort law is at a crossroads. Through 1978, the supreme court has reinained steadfast in its commitment to expand the incidence of liability and distribute accident losses through insurance. Unless the legislature adopts a New Zealand-style comprehensive coinpensation plan, ${ }^{215}$ we can expect continued judicial expansion of liability through the common law process. As a result, tort system costs will continue to rise unless damages are reduced or savings are realized froin increased tort systein efficiency.

In recent years, tort system costs have become an issue of mcreasing public controversy. The most striking example is the medical malpractice insurance "crisis." As the number of malpractice suits and size of awards increased in recent years, inalpractice insurance rates soared and the cost of medical care to patients increased. ${ }^{216}$ The situation reached crisis proportions in 1975 when doctors went on strike and staged slowdowns to protest insurance premium increases. ${ }^{217}$ Medical inalpractice insurance may be only the tip of the iceberg. For example, the legal profession is also experiencing increasing numbers of mal-

215. New Zealand recently abolished the tort action for personal injury and substituted a legislative plan which coinpensates accident victims through an insurance system. See Palmer, Compensation for Personal Injury: A Requiem for the Common Law in New Zealand, 21 AM. J. CoMP. L. 1 (1973).

The possibility of coinprehensive legislative reform does not lessen the need for judicial creativity in tort law. It is always hazardous to predicate conceptions of appropriate judicial lawmaking on hunches regarding the political future. Such hunches can be remarkably inaccurate. For example, the American Medical Association was an early advocate of compulsory national health insurance in the years prior to World War I. In 1914, the AMA Journal announced with approval that "the socialization of inedicine is coming." Margolis, Where Does it Hurt?, THE NEw LEADER, Apr. 15, 1974, at 12. The fact that we have yet to enact a national health insurance plan slould caution those who foresee a "New Zealand Plan" in our near future. One inust also be wary of concluding, as Pound did in 1908, that we have reached the limits of judicial creativity. Compare Pound, Common Law and Legislation, 21 HARv. L. Rev. 383 (1908) with Holmes, The Path of the Law, 10 HARv. L. REv. 457 (1897).

216. For example, in the three or four years prior to 1975 , malpractice rates reportedly increased "roughly" 600\%. Malpractice Crisis, U.S. NEws \& WORLD REP., May 26, 1975, at 32-33. In Cleveland, in 1974, some specialists were reported to be paying as much as $\$ 30,000$ in insurance premiums. Malpractice: MD's Revolt, NEWSWEEK, June 9, 1975, at 58, 60. See generally Freeman, Physicians Not To Blame for Rise in Suits, L.A. Times, Mar. 2, 1975, § 6, at 5, col. 1; States Act to Avert a 'Malpractice Crisis,' Keep Doctors on the Job, Wall St. J., May 6, 1975, at 1, col. 1. See also Citizens' Commission, supra note 155, at 92; Schwartz \& Kamesar, Doctors, Damages and Deterrence, 298 NEw ENG. J. OF MED. 1282 (1978).

217. In some localities, doctors have responded to rate increases, and even the prospect of the unavailability of insurance, with strikes and slowdowns to protest insnrance rates and encourage legislation making insurance available at "reasonable" rates. In New York and Califorma, thousands of doctors refused for various periods of time to perform any but einergency services. Malpractice: Rx for a Crisis, TIME, June 16, 1975, at 49; Malpractice: MD's Revolt, NEwsweEk, June 9,1975 , at 58 . 
practice suits and rising insurance costs. ${ }^{218}$ Even more significant, perhaps, is the claim by manufacturers that the insurance crisis has spread to industry. Preimums paid by some companies for protection agamst products hability suits have been reported to have incrcased by 300 percent or inore in one twelve month period. ${ }^{219}$ Some manufacturers claim that msurance is difficult to obtain or is prohibitively expensive if obtainable. ${ }^{220}$ In addition, similar reports come from the providers of various other goods and services, including restaurants, bars, and school athletic programs. ${ }^{221}$

Businessmen, doctors, and others have urged legislation to lessen their tort liability. ${ }^{222}$ Insurance companies have taken their arguments to legislatures through their lobbyists and to the public througl full and double page ads in national newsmagazines. Typical ads equate product liability with a ticking time bomb and argue that the "sue-somebody syndrome has pushed the cost of product liability insurance to record levels." Readers are exhorted to "[w]rite a letter to your legislators. Be heard." 223 The claims of a tort and imsurance cost crisis havc not fallen on deaf ears. The California Citizens' Commission on Tort Reform was formed in 1976 to conduct "a comprehensive review of the [tort] system."224 In addition, a joint committee of the California legislature is currently examining the entire tort system. ${ }^{225}$

The implicit damages cases can be seen as a tentative response by the supreme court to the increasing public perception of rising tort systein costs. We believe, however, that the court should be cautious before further employing the implicit damages approach. The existence of a severe tort cost crisis lias yet to be established. Many of the claims of a cost crisis are self-serving statements by imsurance compa-

218. Kroll, Professional Malpractice: First Doctors, Now Lawyers, 223 THE NATION 553 (1976); Scott, Legal Malpractice: A Growing Mess, L.A. Times, June 26, 1977, § 7, at 6, col. 1.

219. Insurance: The Sue Syndrome, NewsweEk, Apr. 4, 1977, at 61. See also U.S. Dep'T of Commerce, Interagency Task Force on Product Liability: Final Report V-57 (1977); Product Liability Insurance Rates Jump Sharply, L.A. Times, Oct. 27, 1976, § 3, at 81, col. 1.

220. Citizens' Commission, supra note 155 , at 94.

221. Id; Gustkey, Rising Insurance Rates Threaten Fun and Games, L.A. Times, July 20, 1977, § 3, at 1, col. 1; Insurance: Croquet Anyone?, NewsweEk, Sept. 5, 1977, at 72; Riles Sees Crisis in School Insurance Costs, The San Diego Union, Apr. 6, 1978, § A, at 12, col. 2.

222. See Insurance: The Sue Syndrome, supra note 219 , at $61,62$.

223. Time, Apr. 25, 1977, at 54-55. See also NewsweEk, Apr. 18, 1977, at 62.

224. Citizens' Commission, supra note 155 , at ii. The Commission was started by a grant from the California Medical Association, although the Commission stated that financial sponsorship would have no effect on the direction of the inquiry or on recommendations. Id. at v. Still, one should note that the Commission dealt gingerly with the imsurance industry regarding insurance practices and cost claims. See G. ScHWARTZ, supra note 4, at 31-32. Several insurance coinpany executives were numbers of the Commission. Id.

225. See Assem. Con. Res. 170, res. ch. 160, 1976 Cal. Stats. 6816 (1976) (establishing the Joint Legislative Committee on Tort Liability). 
nies, manufacturers, and medical associations and thus are suspect. ${ }^{226}$ Also, the insurance industry has been reluctant, to date, to allow the scrutiny of its finances ${ }^{227}$ necessary for drawing accurate conclusions. Furthermore, the mere recital of the total anount of liability insurance costs answers few questions. Although the sum may be large, this may simply reflect the fact that accident costs are high im our industrialized society. Similarly, even proof of an increase in the costs of hability insurance does not necessarily mean that we are compensating at an excessive level. One can argue as easily - with medical inalpractice insurance as an example - that premiums were artificially low in the past due to traditional tort doctrime that made it virtually impossible, in practice, for victims of malpractice successfully to brimg suit. 'Thus, rising imsurance rates inay reflect nothing more than an end to past special privileges afforded the medical and other industries. Costs may be "too" high im some objective sense if they seriously discourage the purchasing of hability insurance. Absent proof of such a developinent, however, it is premature to alter damages principles. Such action by the court (or legislature) should only be based on clear evidence that we truly are im a cost crisis.

Even if it is concluded that costs are at a level wliere societal and economic constraints prevent expansion of the mcidence of liability without a concomitant decrease im tort costs, it is questionable whether the implicit dainages approacli is a desirable way of dealing with the problem. An implicit approach to cost problems, as opposed to a direct approach, lias inherent drawbacks.

First, an implicit damages approach muddies tort doctrine, ${ }^{228}$ confusing lawyers and other observers of the court. For example, Borer and Baxter could be viewed as cutting back the Weirum approach to duty questions. Yet, as our earlier analysis suggested, it is clear in Coulter and other recent cases that the Weirum approach is viable when the court perceives the issue to be whether to expand the imcidence of hability. Nevertheless, confusion is likely. ${ }^{229}$ Similarly, although Daly can be explaimed as an implicit damages case, Justice Mosk's fears about the doctrimal effect of the majority opimion cannot be discounted. ${ }^{230}$ Daly relies on notions of comparative fault to reduce plain-

226. See note 223 supra. See generally G. Schwartz, supra note 4, at 1-6.

227. See Citizens' Commission, supra note 155, at 180-81. See also G. Schwartz, supra note 4, at 31-33.

228. See Note, The Supreme Court of California 1976-1977, 66 CALIF. L. REv. 138, 436 (1978).

229. See note 155 supra.

230. In addition, there is the question of jury competence to perform the required task. Justice Jefferson sitting pro tem stated:

The majority's assumption that a jury is capable of making a fair apportionment between a plaintiff's negligent conduct and a defendant's defective product is no more logical or convincing than if a jury were to be instructed that it should add a quart of milk 
tiff recovery. It thus may suggest to some that the court is willing to remtroduce other fault notions imto strict products liability, despite the court's efforts over two decades to extricate fault concepts from enterprise liability cases. Of course, careful readimg of Daly im light of the implicit damages approach, and especially in light of Barker and American Motorcycle, belies such an imterpretation. But, agaim, the Daly opinion invites confusion.

Second, in decisions such as Justus, the use of the implicit damages approach inay cloud discussion of sensitive inoral issues. Justus, for example, makes a statement about the value our society places on the stillbirth of a fetus and the consequent emotional imjury to the parents. More is imvolved than the interpretation of statutory language, technical doctrinal requirenents, or the limiting of intangible damages because of rising tort costs.

Third, even when the implicit damages approach is helpful in solving a recurring legal problein, it is too inexact a inethod to assure proper results in varying fact patterns. For exanple, in discussing Borer, Baxter, and Justus as family damages cases, we are confident that, in general, their effect will be to reduce, but not eliminate, the tort recovery of the family unit and that recovery often will exceed the fainily's tangible loss, even after attorney fees are paid. The family damages approach, lowever, could lead to severe hardship. For example, im individual cases, the real, tangible losses of a parent may be great even though the parent did not witness an injury to a child and even if the dollar value of the child's injuries may be relatively small. In sucl a case, with an action for consortiun eliminated, the family may receive much less than its total losses.

Walters illustrates the dangers of the imphicit damages approach. While the majority opimion demonstrates the attractiveness to the court of this approach, Justice Tobriner's dissent exposes its difficulties. Justice Tobriner placed the Walters issue im the context of inodern Califorma tort law and policy: "[T]he policy of spreading the risk is a sound one, comporting with one of the central themes of modern tort law which atteinpts to ensure that an injured party does not bear a staggering cost as a result of an unfortunate injury." 231 The problem witl the fireman's rule is that it contradicts this policy because it "totally pre-

(representing plaintiffs negligence) and a metal bar three feet in length (representing defendant's strict liability for a defective product), and that the two added together equal 100 percent-the total fault for plaintiff's injuries; that plaintiff's quart of milk is then to be assigned its percentage of the 100 percent total and defendant's metal bar is to be assigned the remaining percentage of the total.

Daly v. General Motors Corp., 20 Cal. 3d 725, 751, 575 P.2d 1162, 1178, 144 Cal. Rptr. 380, 396

(1978) (Jefferson, J., concurring and dissenting).

231. 20 Cal. 3d at 215, 571 P.2d at 619, 142 Cal. Rptr. at 162 (Tobriner, Acting C.J., dissenting) (citations omitted). 
cludes the fireman from recovering [his tort] damages . . . . Thus, instead of spreading the risk of fireman's injuries, the fireman's rule in reality requires the injured fireman personally to shoulder a loss which other employees are not required to bear." ${ }^{232}$ The argument that the compensation of policeinen and firemen reflects the risks they take is weak; indeed, it is reminiscent of the justifications for the harsh tort law governing einployee accidents prior to the enactment of worker coinpensation statutes. ${ }^{233}$ Justice Tobriner wrote that "Califorina decisions have never perceived such theoretical compensation as a sufficient basis for barring the employee's cause of action against a negligent tortfeasor." 234

Moreover, Justice Tobriner identified two deficiencies latent in the implicit damages approach. First, the claim that an individual (or family unit) already is adequately compensated may be untrue. With regard to firemen and policemen, Justice Tobriner believed that it was untrue. Regarding the special disability programs emphasized by the inajority, the court does not present hard data regarding the adequacy of compensation under special disability programs compared with tort recoveries and other recoveries provided other workers. The second deficiency has to do with allusions to, but not proof of, unbearably high costs. Regarding the costs to the judicial system of allowing these actions, Justice Tobriner noted simply that courts are regularly called on to determine the cause of fires in the course of resolving issues relating to liability for property damage or for personal injuries to persons other than firemen. As for the financial burden to the neghigent tortfeasor, Justice Tobriner wrote that the argument appears "to ignore the significant role that insurance presently plays in spreading the risk of loss ainong pohicyholders." ${ }^{235}$ In what could be expanded to a warning applicable to all implicit damages cases, Justice Tobriner wrote: "Courts should be hesitant to cut holes in the carefully woven fabric of the requirement of due care, and to deny to certam selected classifications that protection." 236

The court for the reasons just stated should be wary of its implicit damages approach. Justice Tobriner in Walters, which was decided just six inonths after his family damages opinions in Borer and Baxter, has already shown that he is troubled by inappropriate use of this approach. If the court im the future wishes to limit damages (a result we

232. Id.

233. See generally Friedman and Ladinsky, Social Change and the Law of Industrial Accidents, 67 Colum. L. Rev. 50 (1967).

234. 20 Cal. 3d at 213, 571 P.2d at 617, 142 Cal. Rptr. at 160 (Tobriner, Acting C.J., dissenting).

235. Id. at 216, 571 P.2d at 619, 142 Cal. Rptr. at 162 (Tobriner, Acting C.J., dissenting).

236. Id. at 217, 571 P.2d at 620, 142 Cal. Rptr. at 163 (Tobriner, Acting C.J., dissenting). 
do not feel has yet been shown to be warranted), it should deal directly with traditional tort damages issues. ${ }^{237}$ For example, the court could reverse its past tendency and exert explicit guidance over the size of damage awards. Justice Traynor suggested such a role in Seffert in his analysis of what he considered to be an excessive award for pain and suffering. ${ }^{238}$

If the court dealt directly with traditional damages law, difficult issues would liave to be faced. The collateral source rule currently prevents reduction of a plaintiff's recovery to reflect benefits received from another source, sucl as first-party health insurance. The rule has been the subject of widespread academic criticism as unduly inflating plaintiff's awards. ${ }^{239}$ It thus might be seen as an inviting target for attack. But "inviting targets" may prove to have unexpected complexities. Recognizing that the collateral source rule may result in overcounpensation leads one to consider alternatives to the rule. For example, defendants could be held responsible only for losses above those covered by collateral sources. Or a plaintiff could be compelled to make an election of remedy. Alternatively, a plaintiff could be allowed to pursue all rennedies, with total recovery limited to the maximum amount recoverable from a single source. Choice among the many alternatives necessarily involves difficnlt and delicate judgments. For example, first-party insurance systems generally are far less costly to admmister (per dollar of compensation) than the tort system. ${ }^{240}$ On the other liand, soine have argued ${ }^{241}$ that tort liability serves a valuable function in forcing business enterprises to internalize accident costs, thus providing economic incentives for defendant safety. Relieving defendants of a degree of tort liability might reduce those incentives. Fimally, because of the inultitude of relevant factors involved, different rules might be appropriate for different situations, depending, for example, on the type of collatcral source and the type of defendant or defendant conduct. ${ }^{242}$

Pain and suffering awards might be thought to pose a simpler issue for the court to face directly. Academic criticism of the award has been widespread for solne time. But closer examination reveals serious prac-

237. Some commentators have suggested that the alteration of traditional damages rules, such as those allowing for recovery for pain and suffering, is beyond the scope of appropriate judicial lawmaking. See, e.g., Morris, Liability for Pain and Suffering, 59 CoLUM. L. REv. 476 (1959).

238. Seffert v. Los Angeles Transit Lines, 56 Cal. 2d 498, 512-13, 364 P.2d 337, 346, 15 Cal. Rptr. 161, 170 (1961) (Traynor, J., dissenting). See text accoinpanying notes 129-39 supra.

239. See note 132 supra.

240. See, e.g., R. KeEton \& J. O'Connell, Basic Protection For the Traffic Victim (1965).

241. See note 13 supra.

242. See Fleming, supra note 132. 
tical problems implicit in proposals to abolish or limit this award. In evaluating such proposals, the court would have to decide whether coinpensation for pain and suffering is allowed because it is abstractly correct, or whether sucl compensation is, in reality, a method of giving plaintiffs sufficient coinpensation after payment 'of attorneys' fees. ${ }^{243}$ Under current law, attorneys are compensated on a contingent fee basis. Pain and suffering awards provide a source for payment of these fees. Without such awards, plamtiffs often would be inadequately compensated. Moreover, in practice, some plaintiffs with meritorious claims would recover nothing because attorneys may not find it profitable to take cases with small amounts of damages. For example, it has been suggested that victims with less than $\$ 25,000$ worth of damages will find it difficult to secure the services of an experienced lawyer im products or malpractice cases. ${ }^{244}$ Eliminating or limiting pain and suffering recovery would furtlier imcrease the number of cases which would be uneconomical for attorneys to handle. ${ }^{245}$ Fimally, the pain and suffering award can be seen as a hedge against inflation or as a pragmatic concession that jury awards do not always reflect all future detriment to the plaintiff. ${ }^{246}$

Thus, examination of the collateral source rule and the award for pain and suffering indicates that damages issues cannot be resolved without careful consideration of the practical role the doctrines play within our present adversary tort system. Justice Tobriner's 1970 Helfend opinion, sanctioning the collateral source rule, and his 1977 Walters dissent show a sensitivity to the dangers of reducing damages on an ad hoc basis. In Helfend, he stated, "To permit the defendant to tell the jury that the plaintiff lias been recompensed by a collateral source for his medical costs might irretrievably upset the complex, delicate, and somewhat indefinable calculations which result in the normal jury verdict." 247

243. See generally C. GREGORY \& H. KALVEN, CASES AND MATERIALS ON TORTS 464 (1959).

244. See Schwartz, supra note 42 , at 464.

245. For example, under present law a victim with tangible personal injury damages of $\$ 10,000$ inight in certain cases be able to recover $\$ 30,000$ for pain and suffering. Elimination of the paim and suffering award would reduce his total recovery from $\$ 40,000$ to $\$ 10,000$. If the attorney fees were $\$ 4,000$, the plaintiff would recover $\$ 6,000$-that is, $\$ 4,000$ less than his tangible loss. The inore severe problem is that he might recover nothing because an attorney might not find it profitable to take the case.

246. See generally Kalven, The Jury, The Law, and The Personal Injury Award, 19 OHIо ST. L.J. 158 (1958).

247. 2 Cal. 3d at $11-12,465$ P.2d at 68, 84 Cal. Rptr. at 180 (citations omitted). Accord, McWeeney v. N.Y., N.H. \& H.R.R., 282 F.2d 34 (2d Cir.) (Friendly, J.), cert. denied, 364 U.S. 870 (1960). 


\section{CONCLUSION}

In this Article we have argued that the California Supreme Court continues today, as it has for twenty years, to mcrease the incidence of tort liability. During the 1960's and 1970's, the court created a new doctrine of strict products liability. At the same time, it persistently eliminated doctrines that exempted defendants from negligence hability. This trend has continued in 1978, as shown by Cooper, Barker, and Coulter. During most of the years that the court was expanding the incidence of liability, it allowed the steady growth of damages, frequently over objections by Justice Traynor. Since 1977, however, the court has begun to limit the amount of damages recoverable, perhaps in response to a concern over rising tort system costs. This trend has not yet been broadly recognized because the court has not exphicitly altered damages principles. Rather, damages have been limited imdirectly in cases in which, for example, the fornal issue presented to the court was whether the plaintiff had stated a cause of action. Borer $v$. American Airlines and Baxter v. Superior Court were two cases analyzed in this Article as "implicit damages" cases. Although the formal holdings in these cases refused to recognize causes of action for loss of parent-child consortium, we argued that these and similar cases are best viewed as damages cases. The practical effect of Borer and Baxter is to limit, but not eliminate, tort damages recoverable by a family unit.

The implicit daniages analysis that we have developed in this Article is a useful tool for understanding recent California Supreme Court decisions. But merely showing that the concept is useful for describing past cases and predicting future trends ${ }^{248}$ is less important than ques-

248. Hoyem v. Manhattan Beach Sch. Dist., 22 Cal. 3d 508, 585 P.2d 851, 150 Cal. Rptr. 1 (1978), was decided after this Article was written. Hoyem is of interest because (1) it involves a clear incidence of liability issue; (2) it also involves what we have called implicit damages issues; and (3) one of the three dissenting Justices expressly relied on the alleged tort and insurance cost "crisis" as a reason to refuse to expand tort liability.

In Hoyem, the court, in an opinion by Justice Tobriner, expanded school district tort liability to include children who were injured while truant due to the school's negligent supervision. Justice Richardson, in a dissent joined by Justice Mosk, wrote that for policy reasons a "line should be drawn limiting a school's liability to injuries to a pupil which occur on school property, or when the pupil is transported to, or participating in, a scliool-sponsored or school-related activity ... ." Id. at 527-28, 585 P.2d at 863, 150 Cal. Rptr. at 13 (Richardson, J. dissenting). The court refused to draw such a "duty" line, however. Instead it once again expanded the incidence of hability. Justice Tobriner wrote that if the plaintiff "can prove that the pupil's injury was proximately caused by the school district's negligent supervision, the district may be held liable for the resultant damages." Id. at 512,585 P.2d at 852,150 Cal. Rptr. at 2. On this basis the court held that the child's complaint stated a cause of action even though he was injured outside the school premises.

In dissent, Justice Clark characterized the court's holding as "grounded on a policy determination that, in their view, yet another element of society should be afforded an insured's proteetion against mishap." Id. at 525, 585 P.2d at 861, 150 Cal. Rptr. at 11. He strongly objected to the court's holding, citing the tort and insurance cost "crisis." 
tioning whether the use of the implicit damages approach is desirable. Our conclusion is that alarm over tort costs is premature. Moreover, an implicit, rather than direct, style of dealing with damages issues is frequently inappropriate and fraught with danger. Nevertheless, it is likely that damages issues will increasingly occupy the court's attention in the next decade. The resolution of these issues will call for at least as much judicial creativity as the court has demonstrated in the past two decades in expanding the incidence of tort liability.

Hoyem also deals with issues which we have characterized as implicit damages issues. Specifically, the injured child's mother asserted a cause of action for loss of consortium and for negligent infliction of emotional distress. The Hoyem court followed the direction charted in previous implicit damages cases. First, in accord with Baxter v. Superior Court, 19 Cal. 3d 461, 563 P.2d 871, 138 Cal. Rptr. 315 (1977), it held that the mother had no cause of action for loss of consortium. 22 Cal. 3d at 522, 585 P.2d at 859, 150 Cal. Rptr. at 9. Second, the court reinforced the conclusion reached in our discussion of Justus v. Atchison, 19 Cal. 3d 564, 565 P.2d 122, 139 Cal. Rptr. 97 (1977), see notes 162-77 and accompanying text supra: it is strictly interpreting the requirements for recovery for emotional distress laid down in Dillon v. Legg, 68 Cal. 3d 728, 441 P.2d 912, 68 Cal. Rptr. 72 (1968). As this Article has discussed previously, these Hoyem holdings can be viewed as reducing the tort recovery of the family unit-as implicit damages cases. Thus, the California Supreine Court in Hoyem expanded the incidence of tort liability by allowing a cause of action against the school district and, at the same time, continued its more restrictive approach to damages issues. 